\title{
FUNDAMENTALIDADE E EFETIVIDADE DA DEFESA DO CONSUMIDOR
}

\author{
ADALBERTO PASQUALOTTO*
}

\begin{abstract}
RESUMO: O presente artigo vislumbra o consumo básico como componente do mínimo existencial e, por conseguinte, a defesa do consumidor como direito humano. No contexto brasileiro, estuda a eficácia da defesa do consumidor como direito fundamental e aponta a omissão do Estado como responsável pela ausência de importantes mecanismos de implementação do sistema protetivo previsto no Código de Defesa do Consumidor.

PALAVRAS-CHAVE: Defesa do Consumidor. Direitos Fundamentais. Constituição. Efetividade.
\end{abstract}

\begin{abstract}
The present article perceives basic consuming as an existential minimum's component and, therefore, consumer protection as a human right. In the Brazilian framework, it studies the efficacy of the fundamental right to consumer protection and points out the State's omission as acknowledgeable for the lack of important implementation mechanisms of the protective system prescribed in the Code of Consumer Protection.

KEYWORDS: Consumer Protection. Fundamental Rights. Constitution. Efficacy.
\end{abstract}

SUMÁRIO: Introdução; I. O caráter humano e fundamental da defesa do consumidor no Brasil; II. Constituição e defesa do consumidor; III. Projeções infraconstitucionais da defesa do consumidor; IV. A política e a efetividade da defesa do consumidor no Brasil; Conclusão.

SUMMARY: Introduction; I. The human and fundamental character of consumer protection in Brazil; II. Constitution and consumer protection; III. Infra-constitutional projections of consumer protection; IV. Consumer protection's policy and effectiveness in Brazil; Conclusion.

\section{INTRODUÇÃO}

A defesa do consumidor consagrou-se no Brasil, em um primeiro momento, como uma novidade trazida pela Constituição de 1988, pois do tema até então pouco se falava e só alguns especialistas nele eram versados. Em seguida, assumiu importante lugar no conceito de cidadania, incorporada à idéia de exercício pessoal que o cidadão poderia fazer dos seus direitos na esfera quotidiana de interesses imediatos. Contribuiu, assim, para transmitir à população a consciência de que a dignidade de cada um, compreendida pela exigibilidade de respeito aos direitos individuais, não é

Artigo recebido em 7.10.2009 e aprovado para publicação pelo Conselho Editorial em 10.12.2009.

* Professor Adjunto da Faculdade de Direito da PUCRS; ex-presidente do BRASILCON - Instituto Brasileiro de Política e Direito do Consumidor; Procurador de Justiça aposentado (MP/RS). 
tema privativo de letrados nem pauta meramente acadêmica e distanciada em definitivo do homem comum. Muito ao contrário. Incentivou a defesa pessoal do consumidor junto ao fornecedor e provocou o acesso a órgãos públicos antes inexistentes e criados para dar guarida aos reclamos dos que, mesmo depois da irresignação pessoal, não se viram atendidos pelos fornecedores faltosos. Nessa medida, a defesa do consumidor também serviu para demonstrar a disponibilidade do aparelho estatal e, outra vez, a nova proximidade que era estabelecida entre o cidadão e o Estado.

Passados quase vinte anos da promulgação do CDC, ocorrida em 1990, não há mais dúvida da sua importância no contexto histórico do quadro jurídico do direito privado nacional, especialmente porque o novo Código Civil só veio doze depois, ensejando que a lei máxima dos consumidores, interpretada de modo extensivo, servisse de suporte a uma onda de renovação do direito das obrigações, especialmente no campo dos contratos e da responsabilidade civil, espelhada de modo muito significativo na jurisprudência do Superior Tribunal de Justiça.

O presente ensaio procura destacar a importância da defesa do consumidor no estágio evolutivo das idéias sociais e jurídicas hoje vigente. Já não se duvida que ela faz parte do amplo espectro identificado como direitos humanos aplicados ao campo social, os quais, protegidos na Constituição, constituem direitos fundamentais do cidadão e da sociedade brasileira. A defesa do consumidor é direito fundamental individual e também coletivo. Mas não é só. Da Constituição a defesa do consumidor irradia reflexos na ordem econômica, sendo um dos seus princípios básicos, integrada ao regime capitalista brasileiro par a par com a livre iniciativa, da qual é um fator de ponderação, contribuindo para uma sociedade econômica e socialmente mais justa e solidária.

O primeiro capítulo trata do direito do consumidor conceituado como direito humano e incluído na Constituição como direito fundamental. Há um consumo básico que deve ser considerado como mínimo existencial do consumidor. É em defesa do fornecimento digno desse mínimo que se impõe a defesa jurídica do consumidor. Entretanto, essa defesa em nada afeta o princípio da igualdade, o que é importante destacar porque ela tem como pressuposto a vulnerabilidade do consumidor, justificando-se por ser uma forma de compensação de situações de desequilíbrio impostas pelo mercado, locus das trocas, onde o consumidor vai buscar os bens e sérvios de que necessita.

O segundo capítulo vislumbra as fontes normativas internacionais da defesa do consumidor e como elas deram entrada na Carta de 1988. Traça o entremeado da defesa do consumidor com os direitos humanos e os direitos constitucionais fundamentais, concluindo por examinar os dois dispositivos essenciais nessa matéria, os artigos $5^{\circ}$, inciso XXXII e 170, inciso V.

O terceiro capítulo cuida dos reflexos infraconstitucionais da defesa do consumidor, especialmente do Código de Defesa do Consumidor, que concretiza os mandamentos constitucionais. São feitas breves considerações sobre a autonomia científica do direito do consumidor e em seguida procura-se precisar o campo de aplicação da legislação protetiva, especialmente em face da hipótese de se considerar consumidoras as pessoas jurídicas.

DIREITOS FundAMENTAIS E JUSTIÇA N 9 - OUT./DEZ. 2009 
Finalmente, o último capítulo faz reflexões sobre a Política Nacional das Relações de Consumo e, a partir da escassez de dados disponíveis, uma pequena análise crítica sobre a efetividade das normas legais.

\section{O CARÁTER HUMANO E FUNDAMENTAL DA DEFESA DO} CONSUMIDOR NO BRASIL

Embora se empregue a expressão “defesa do consumidor” no singular, em essência se trata de uma questão coletiva. Nela não se falaria na ausência da sociedade massificada em que se vive. Uma das principais vítimas da massificação é a individualidade como nota valorativa da diferença. Os seres humanos já não são tratados como pessoas, mas como dados estatísticos. O consumidor é referido nos planos de marketing como alvos quantitativos e qualitativos a serem atingidos. Na ponta da execução, esses planos não deixam espaço para ouvir o indivíduo que está na destinação final do produto ou do serviço levado ao mercado. E assim surge o desequilíbrio entre o fornecedor e o consumidor.

Neste primeiro capítulo, será considerado o consumo como componente do conceito de mínimo existencial e a perspectiva de defesa coletiva dos consumidores frente à massificação, bem como a contribuição da defesa do consumidor para a preservação do princípio da igualdade material.

\section{O consumo básico como mínimo existencial do ser humano} humana.

O direito do consumidor é direito humano porque o consumo é necessidade

Na Declaração dos Direitos Humanos, da ONU, o consumo adquire a perspectiva de essencialidade e de mínimo existencial, caracterizando o conjunto de bens indispensáveis ao provimento das necessidades básicas do indivíduo e da família. A Declaração reconhece a todo ser humano o direito à segurança social (art. XXII) ${ }^{1}$, a uma remuneração justa e satisfatória, que lhe assegure, e à sua família, uma existência compatível com a dignidade humana (art. XXIII, 3) ${ }^{2}$ e, finalmente, a um padrão de vida capaz de assegurar saúde e bem-estar, inclusive alimentação, vestuário, habitação, cuidados médicos e os serviços sociais indispensáveis (art. XXV, 1). ${ }^{3}$

A Organização Pan-americana de Saúde, reunida em Washington de 25 a 29 de setembro de 2006, ressaltou a importância do consumo de alimentos sadios no combate às enfermidades crônicas. Do encontro, resultou o documento denominado “Estratégia regional e plano de ação para um enfoque integrado sobre a prevenção e

\footnotetext{
${ }^{1}$ Artigo XXII. Todo ser humano, como membro da sociedade, tem direito à segurança social, à realização pelo esforço nacional, pela cooperação internacional e de acordo com a organização e recursos de cada Estado, dos direitos econômicos, sociais e culturais indispensáveis à sua dignidade e ao livre desenvolvimento da sua personalidade.

${ }^{2}$ Art. XXIII. (...). 3. Todo ser humano que trabalha tem direito a uma remuneração justa e satisfatória, que lhe assegure, assim como à sua família, uma existência compatível com a dignidade humana e a que se acrescentarão, se necessário, outros meios de proteção social.

${ }^{3}$ Artigo XXV. 1. Todo ser humano tem direito a um padrão de vida capaz de assegurar-lhe, e a sua família, saúde e bem-estar, inclusive alimentação, vestuário, habitação, cuidados médicos e os serviços sociais indispensáveis, e direito à segurança em caso de desemprego, doença, invalidez, viuvez, velhice ou outros casos de perda dos meios de subsistência em circunstâncias fora de seu controle.
} 
o controle das enfermidades crônicas, incluindo o regime alimentar, a atividade física e a saúde". ${ }^{4}$ Inicialmente, o documento conjuga dados estatísticos impressionantes de mortandade devida a enfermidades crônicas, tais como 35 milhões de vítimas de doenças crônicas no mundo em 2005. Na América Latina e Caribe, no mesmo ano, havia 35 milhões de portadores de diabetes. A hipertensão, um dos fatores de risco mais importantes para as cardiopatias, afeta de $8 \%$ a $30 \%$ dos habitantes da região. O câncer, além de ser a causa de $20 \%$ das mortes por enfermidades crônicas, produziu, em 2002, 459 mil disfunções. São apontadas como fatores de risco para as enfermidades crônicas a falta de nutrição adequada e a inatividade física. No pertinente ao primeiro ponto, é referido o escasso consumo de frutas, verduras, grãos integrais, cereais e legumes, aliado a um consumo relativamente alto de alimentos ricos em gorduras saturadas, açúcares e sal, como leite, carnes, cereais refinados e alimentos processados.

O direito do consumidor torna-se relevante para o combate aos males decorrentes da desnutrição, não porque tenha por objeto o abastecimento, mas a qualidade dos alimentos. Ademais, as questões de alimentação tocam diretamente com a educação para o consumo e a informação, dois direitos básicos assegurados no art. $6^{\circ}$ do Código de Defesa do Consumidor. ${ }^{5}$ Portanto, o direito do consumidor não é secundário na ciência jurídica. Ao contrário, porquanto lida com o essencial da vida humana, conecta-se com os princípios da dignidade da pessoa e a garantia do mínimo existencial - mínimo existencial entendido como "conjunto de garantias materiais para uma vida condigna”. ${ }^{6}$ Como relata Ingo Sarlet, reportando a evolução doutrinária e jurisprudencial germânica nessa matéria, "sem os recursos materiais para uma existência digna, a própria dignidade da pessoa humana ficaria sacrificada”. ?

Transpondo a idéia de mínimo existencial para as relações de consumo, pode-se falar de um consumo básico como direito fundamental. Não apenas um direito à alimentação como pressuposto de saúde e sustento físico, mas incluindo o acesso a outros bens que atualizam o significado de direitos fundamentais de primeira geração. Como corretamente observa Geisa de Assis Rodrigues, direitos individuais clássicos como a inviolabilidade de domicílio, a proteção da integridade física e a liberdade de manifestação do pensamento só são viáveis se assegurados os pressupostos da existência de um lar, da assistência à saúde e do acesso à educação formal. ${ }^{8}$

Não tendo havido, no Brasil, a expressa garantia constitucional do mínimo existencial, é a defesa do consumidor, tal como posta na Constituição, um dos suportes

\footnotetext{
${ }^{4}$ Disponível em http://www.paho.org/spanish/gov/cd/CD47-17rv-s.pdf. Acesso em 21 jul. 2009.

${ }^{5}$ A noção de direitos humanos abrangendo os direitos do consumidor - e particularmente o direito à educação relativa à aquisição de bens essenciais - era defendida já em 1983 por Luiz Amaral, na introdução à coletânea de textos legais sobre relações de consumo (BRASIL. Relações de consumo. 2. ed. MIC/Conselho de Desenvolvimento Comercial e Fundação Petrônio Portella, 1983, 4 v (Coleção textos legais, 8), v. 1, p. X.

${ }^{6}$ SARLET, Ingo Wolfgang. Direitos fundamentais sociais, mínimo existencial e direito privado. Revista de Direito do Consumidor, vol. 61, jan.-mar. 2007, p. 90-125 (103).

${ }^{7}$ SARLET, Ob. cit., p. 100.

${ }^{8}$ RODRIGUES, Geisa de Assis. A proteção ao consumidor como um direito fundamental. Revista de Direito do Consumidor, vol. 58, abr.-jun. 2006, p. 75-97 (94).
} 
desse reconhecimento, tendo em vista o conteúdo amplo dos direitos do consumidor consagrado primeiramente nos documentos internacionais e, pós-constituição, no CDC. Tendo por objeto toda aquisição de produtos e toda prestação de serviços, incluindo até mesmo a prestação de serviços públicos, o Código de Defesa do Consumidor se presta a tutelar a qualidade de bens e serviços essenciais à vida digna e saudável, tais como alimentos, medicamentos, serviços de assistência à saúde em geral, vestuário, habitação, educação, crédito, seguros, previdência etc. Desse modo, o CDC compensa as desigualdades do mercado, sendo instrumento de garantia do mínimo existencial, uma vez que, conforme registra Sarlet, as relações entre particulares (no caso, entre fornecedores e consumidores) não são apenas horizontais, mas também verticais, em vista da disparidade de poder social de que são detentores. ${ }^{9}$

\section{O universalismo das necessidades e a coletivização dos interesses}

$\mathrm{O}$ atendimento das necessidades humanas básicas, vale dizer, o consumo mínimo para uma existência digna, deve ser considerado em perspectiva ultraindividual, haja vista a complexidade social e econômica em que desdobra a vida massificada de hoje. O Código de Defesa do Consumidor reflete, no atinente ao consumo, a nota inerente à universalidade dos direitos fundamentais, cujo conteúdo deve responder aos interesses e às expectativas de todos.

$\mathrm{O}$ art. $2^{\circ}$, parágrafo único, ao equiparar a coletividade a consumidor, estabelece um centro de atribuição jurídica que ultrapassa o indivíduo. A coletividade de consumidores, embora não requeira personificação, pode fazer-se representar em juízo na defesa dos seus interesses e direitos, pelas entidades legalmente legitimadas, dispostas no art. 82: o Ministério Público, as entidades federativas, os órgãos da administração direta ou indireta destinados especificamente à defesa dos consumidores (geralmente chamados de Procon's) e as associações de consumidores.

Os direitos de que é titular a coletividade de consumidores são de três ordens: direitos difusos (que são direitos coletivos em sentido amplo), correspondentes a pessoas indetermináveis, ligadas entre si por mera circunstância de fato, como o direito positivo à boa prestação dos serviços públicos ou o direito negativo a não ser alvo de publicidade enganosa ou abusiva; direitos coletivos em sentido estrito, correspondentes a grupos de pessoas juridicamente vinculadas entre si ou com a parte contrária, como os beneficiários de um plano de assistência médica ou os prestatários (consumidores de serviços) de uma operadora telefônica; e os direitos individuais homogêneos, direitos que, embora substancialmente individuais, comportam defesa coletiva, como a indenização de danos causados por produtos defeituosos. Neste caso, socorre as vítimas, também em dimensão coletiva, o art. 17. Também o art. 29 é representativo de universalidade, ao proteger todas as pessoas expostas às práticas comerciais, incluindo-se a publicidade, a oferta de produtos e serviços e os contratos de adesão. Note-se, porém, que os artigos 17 e 29 acabam por se reconduzir às três categorias mencionadas inicialmente, conforme a situação fática.

\footnotetext{
${ }^{9}$ SARLET, Ingo Wolfgang. Direitos fundamentais sociais, mínimo existencial e direito privado. Revista de Direito do Consumidor, vol. 61, jan.-mar. 2007, p. 108.
} 
Enquanto direito difuso, a proteção ao consumidor é um direito humano de terceira geração, incluído entre os direitos fundamentais coletivos, conforme a classificação de José Afonso da Silva, porque pertencente a um homem-membro de uma coletividade (a dos consumidores). ${ }^{10}$

\section{A defesa do consumidor e o princípio da igualdade}

Ao contrário do que possa parecer, por se tratar de um direito protetivo, a defesa ao consumidor não contraria o princípio da igualdade. É, ao revés, meio de realizá-lo. Como explica Ferrajoli, ao corresponder aos interesses e à expectativa de todos, dado o seu caráter universal, os direitos fundamentais constituem a base da igualdade jurídica e os direitos patrimoniais a base da desigualdade. Por conseguinte, os direitos fundamentais são a dimensão substancial da democracia, que é prévia à dimensão política ou formal. No Estado democrático de direito, a dimensão substancial, que no Estado moderno compreendia apenas os direitos de liberdade e propriedade, ampliou-se na perspectiva do Estado social, incluindo expectativas vitais como a saúde, a educação e a subsistência. ${ }^{11}$

Os direitos de liberdade e de propriedade mesclaram-se numa mesma categoria em virtude da justaposição das doutrinas jusnaturalista e da tradição civilista e romanista. Essa mescla, operada pelo liberalismo, condicionou até nossos dias a teoria dos direitos em sua totalidade e a própria noção de estado de direito. Mas, aponta Ferrajoli, há um equívoco na base desse raciocínio. No conceito de direito de propriedade entram duas noções distintas: o direito a ser proprietário e de dispor livremente dos próprios direitos - que é um direito civil fundamental -, e a propriedade de um determinado bem - que é um direito patrimonial. A indistinção dessas duas noções levou a dupla distorção: o pensamento liberal a equiparar o direito de propriedade à liberdade e o pensamento marxista a desacreditar a propriedade como direito burguês. ${ }^{12}$

A igualdade em concreto como objetivo do direito do consumidor usa como instrumento a justiça distributiva. ${ }^{13}$ A igualdade é um ponto intermediário, conforme Aristóteles, e quem não é igual não pode receber coisas iguais. ${ }^{14} \mathrm{~A}$ justiça distributiva, que em Aristóteles tinha o sentido de "distribuição de honras, de dinheiro ou das outras coisas que são divididas (...)”, 15 adquiriu nova significação na revolução

${ }^{10}$ SILVA, José Afonso da. Curso de direito constitucional positivo. 27. ed. São Paulo: Malheiros, 2006, p. 184. A classificação dos direitos humanos é bastante relativa e varia muito com os autores e no tempo, segundo Cançado Trindade. A categorização em direitos individuais (primeira geração), sociais (segunda geração) e de solidariedade ou dos povos ou coletivos (terceira geração), é apenas mais uma e não pode representar antinomia, mas complementaridade, sendo que os direitos de solidariedade interagem com os dois primeiros (TRINDADE, Antônio Augusto Colaço. A proteção internacional dos direitos humanos. São Paulo: Saraiva, 1991, p. 38-41).

${ }^{11}$ FERRAJOLI, Luigi. Derechos y garantias: la ley del más débil. Tradução para o espanhol de Perfecto Andrés Ibáñez e Andréa Greppi. 2. ed. Madrid: Editorial Trotta, 2001, p. 42.

${ }^{12}$ FERRAJOLI, Ob. cit., p. 45.

${ }^{13}$ Sobre a importância da justiça distributiva no direito do consumidor: LOPES, José Reinaldo Lima. O aspecto distributivo do direito do consumidor. Revista de Direito do Consumidor, v. 41, jan.-mar. 2002, p. 140-150.

${ }^{14}$ ARISTÓTELES. Ética a Nicômaco. Os pensadores, vol. IV. São Paulo: Victor Civita, 1973, p. 325.

${ }^{15}$ ARISTÓTELES. Ob. cit., p. 324. 
francesa com Babeuf, quando proclamou que a justiça exige que o Estado redistribua bens para os pobres. ${ }^{16}$ Uma das inspirações de Babeuf teria sido um discurso de Armand de la Meuse perante a Assembléia Nacional francesa, em 17 de abril de 1793, dizendo que "não poder haver ... uma contradição mais perigosa, absurda e imoral do que a igualdade política sem igualdade social e econômica". ${ }^{17}$ Mudou-se assim a concepção meritória que a justiça distributiva tinha em Aristóteles. A distribuição deve ser feita independentemente do mérito. ${ }^{18}$

O conceito atual de justiça distributiva, frisa Fleischacker, exige que o Estado garanta a propriedade de modo que todos possam ser supridos de um certo nível de recursos materiais. ${ }^{19}$ Ou em Rawls: a noção econômica de bem púbico deve basear-se numa concepção de justiça ou de divisão justa das vantagens sociais. ${ }^{20}$

Para Rawls, a justa distribuição de bens e serviços depende da existência de instituições políticas e jurídicas adequadas, respeitando-se as peculiaridades de cada sociedade. ${ }^{21}$ Essas instituições compreendem uma constituição justa, que assegure as mesmas liberdades de cidadania para todos, oportunidades iguais de educação e cultura, igualdade de oportunidades nas atividades econômicas e na livre escolha de ocupação e um mínimo social a todos. Para implantar essas instituições de fundo, Rawls preconiza que o Estado se divida em quatro setores de atividades, que podem ser desenvolvidas por uma diversidade de órgãos: o setor de alocação, responsável por manter um sistema de preços competitivo e pela correção dos desvios de eficiência; o setor de estabilização, que deve responder pelo pleno emprego e pelo acesso ao crédito; o setor de transferências, que deve proporcionar o mínimo social [mínimo existencial], considerando-se que "um sistema competitivo de preços não leva em conta as necessidades e, portanto, não pode ser o único instrumento de distribuição"; e o setor de distribuição propriamente dito, cuja função é cuidar de uma tributação justa. ${ }^{22}$

Para Ronaldo Porto Macedo Júnior, a concepção de justiça distributiva apresenta três aspectos distintos: reequilibra as relações de poder, desenvolve uma concepção welfarista de justiça contratual e propõe o direito como instrumento de modificação

${ }^{16}$ FLEISCHACKER, Samuel. Uma breve história da justiça distributiva. São Paulo: Martins Fontes, 2006, p. 113.

${ }^{17}$ FLEISCHACKER, Ob. cit., p. 113.

${ }^{18}$ FLEISCHACKER, Ob. cit., p. 9 e 163. Em relativa discordância com esse ponto-de-vista, mas irrelevante para os fins deste texto, Villey afirma que Aristóteles não tratou propriamente de justiça, mas de duas espécies de igualdade: a igualdade geométrica em matéria de distribuição e a igualdade aritmética em matéria de comutação. Na distribuição, o discurso jurídico tende a exprimir uma proporção e nas trocas, uma equivalência (VILLEY, Michel. Philosophie du droit. Paris: Dalloz, 2001, p. 58-61.

${ }^{19}$ FLEISCHACKER, Ob. cit., p. 8.

${ }^{20}$ RAWLS, John. Uma teoria da justiça. 3. ed. Trad. de Jussara Simões. São Paulo: Martins Fontes, 2008, p. 322.

${ }^{21}$ Para Rawls, "não há vínculo essencial entre o emprego de mercados livres e a propriedade privada dos meios de produção", de tal modo que o regime socialista pode valer-se das vantagens da economia de mercado (RAWLS, John. Uma teoria da justiça. 3. ed. Trad. de Jussara Simões. São Paulo: Martins Fontes, 2008, p. 337-338).

${ }^{22}$ RAWLS, John. Uma teoria da justiça. 3. ed. Trad. de Jussara Simões. São Paulo: Martins Fontes, 2008, p. 342 e ss. 
da sociedade e particularmente o direito do consumidor como mecanismo de acesso à cidadania. $^{23}$

O CDC usa diversos instrumentos de justiça distributiva, $v . g .:$ a responsabilidade civil objetiva do fornecedor por defeito dos produtos e serviços; a responsabilidade por vícios; a desconsideração da personalidade jurídica; a vinculatividade da oferta; a vedação de práticas mercadológicas abusivas; a proteção contratual, especialmente o direito de arrependimento; a nulidade de cláusulas contratuais abusivas; e no plano processual, a inversão do ônus da prova.

\section{CONSTITUIÇÃO E DEFESA DO CONSUMIDOR}

No Brasil, a hierarquia constitucional da defesa do consumidor é inequívoca, decorrente de texto constitucional expresso. Além da constitucionalidade formal, pode-se falar de uma constitucionalidade material da defesa do consumidor, que não se manifesta apenas no direito interno, mas é reconhecida em documentos internacionais e alinha-se na perspectiva dos direitos humanos.

\section{Origens e fontes normativas do direito do consumidor}

A importância da proteção ao consumidor no mundo atual é retratada pelo ingresso da sua normatividade em algumas cartas constitucionais, seguindo a diretriz de documentos internacionais. ${ }^{24}$

No plano internacional, o primeiro documento de importância foi originário da Comissão para a Política dos Consumidores, formada no seio da OCDE-Organização para a Cooperação e o Desenvolvimento Econômico, publicada em 1969, e que foi a base da Resolução do Conselho da Europa, que editou em 15 de abril de 1973 a chamada Carta dos Consumidores. Nascia nessa ocasião o consumidor como sujeito jurídico. A Carta estruturou cinco grupos de direitos básicos: a) eficaz proteção contra os riscos atentatórios à saúde e à segurança; b) eficaz proteção contra lesões aos seus interesses econômicos; c) disponibilidade de meios adequados de assistência e ressarcimento de danos; d) informação e educação; e) consulta e representação nas deliberações que lhes dizem respeito.

Após esse marco, os países membros da União Européia passaram a integrar a proteção aos consumidores em sua legislação interna, seguindo as diretivas comunitárias, que já são numerosas, e que podem ser assim resumidas, conforme o ano de expedição, número de identificação e matéria de que tratam: 84/450 (publicidade enganosa); 85/577 (contratos negociados fora dos estabelecimentos comerciais); 87/102, 90/88 e 2008/48 (contratos de crédito aos consumidores); 89/395 (rotulagem, apresentação e publicidade de gêneros alimentícios); 97/55 (publicidade comparativa); 85/374 e 99/34 (produtos defeituosos); 88/378 (segurança de brinquedos); 90/314 (viagens e

\footnotetext{
${ }^{23}$ MACEDO JÚNIOR, Ronaldo Porto. Contratos relacionais e a defesa do consumidor. 2. ed. São Paulo: Revista dos Tribunais, 2007, p. 231.

${ }^{24}$ Para um histórico da evolução da proteção ao consumidor em vários países e no Brasil, entre outros: ALMEIDA, João Batista de. A proteção jurídica do consumidor. 2. ed. São Paulo: Saraiva, 2000; FILOMENO, José Geraldo Brito. Manual de direitos do consumidor. São Paulo:Atlas, 1991; GAMA, Hélio Zaghetto. Curso de direito do consumidor. 2. ed. Rio de Janeiro: Forense, 2004; SIDOU, J. M. Othon. Proteção ao consumidor. Rio de Janeiro: Forense, 1977.
} 
turismo); 92/59 e 2001/95 (segurança geral de produtos); 93/13 (cláusulas contratuais abusivas); 93/22 (investimentos em valores mobiliários); 93/99 (controle de gêneros alimentícios); 94/47 (aquisição imobiliária para desfrute em tempo parcial [time sharing]); 95/46 (bancos de dados); 97/7 (contratos a distância), 2002/65 (comercialização a distância de serviços financeiros); 99/44 (venda de bens de consumo e garantias a eles relativas); 98/6 (indicações de preços dos produtos oferecidos aos consumidores); 2005/60, 2006/48 e 2007/64 (sistemas de pagamentos no mercado interno); 99/93 (contratos eletrônicos); 94/10 e 98/34 (informação de normas e regulamentações técnicas); 2000/31 (serviços da sociedade da informação, especialmente o comércio eletrônico); 2001/46 (alimentação animal); 2005/29 (práticas comerciais desleais); 2005/84 (colocação no mercado e utilização de substâncias e preparações perigosas); 2007/46 (homologação de veículos a motor e reboques); 2009/22 (ações inibitórias de proteção dos interesses dos consumidores).

Outro marco europeu importante, acima das diretivas, foi o Tratado de Maastricht, de 7 de fevereiro de 1992, que introduziu no Tratado de Roma o Título XV, o capítulo específico “A defesa dos consumidores”.

Alguns países europeus puseram uma diretriz de proteção ao consumidor na própria Constituição. Assim o fizeram a Espanha e ${ }^{25}$ Portugal. $^{26}$ Na América do Sul, ocorreu o mesmo na Argentina (1994). ${ }^{27}$

\footnotetext{
${ }^{25}$ Dispõe o art. 51, da Constituição espanhola, reformado em 1978: 1. Los poderes públicos garantizarán la defensa de los consumidores y usuários, protegiendo, mediante procedimientos eficaces, la seguridad, la salud y los legitimos interesses económicos de los mismos. 2. Los poderes públicos promoverán la información y la educación de los consumidores y usuarios, fomentarán sus origanizaciones y oirán a éstas en las cuestiones que puedan afectar a aquéllos, en los términos que la ley establezca. 3. En el marco de lo dispuesto por los apartados anteriores, la ley regulará el comercio interior y el régimen de autorización de productos comerciales. Em tradução livre: "Os poderes públicos garantirão a defesa dos consumidores e usuários, protegendo, mediante procedimentos eficazes, a segurança, a saúde e os legítimos interesses econômicos dos mesmos. Os poderes públicos promoverão a informação e a educação dos consumidores e usuários, fomentarão suas organizações e as ouvirão em questões que possam afetálos, nos termos que a lei estabelecer. Para cumprir essas disposições, a lei regulará o comércio interno e o licenciamento de produtos comerciais”.

${ }^{26}$ Artigo 60. ${ }^{\circ}$ Direitos dos consumidores. 1. Os consumidores têm direito à qualidade dos bens e serviços consumidos, à formação e à informação, à proteção da saúde, da segurança e dos seus interesses econômicos, bem como à reparação de danos. 2. A publicidade é disciplinada por lei, sendo proibidas todas as formas de publicidade oculta, indireta ou dolosa. 3. As associações de consumidores e as cooperativas de consumo têm direito, nos termos da lei, ao apoio do Estado e a ser ouvidas sobre as questões que digam respeito à defesa dos consumidores, sendo-lhes reconhecida legitimidade processual para defesa dos seus associados ou de interesses coletivos ou difusos.

Artigo 81. ${ }^{\circ}$ Incumbências prioritárias do Estado. Incumbe prioritariamente ao Estado no âmbito económico e social: (...) i) Garantir a defesa dos interesses e os direitos dos consumidores; (...).

${ }^{27}$ Artículo 42- Los consumidores y usuarios de bienes y servicios tienen derecho, en la relación de consumo, a la protección de su salud, seguridad e intereses económicos; a una información adecuada y veraz; a la libertad de elección, y a condiciones de trato equitativo y digno. Las autoridades proveerán a la protección de esos derechos, a la educación para el consumo, a la defensa de la competencia contra toda forma de distorsión de los mercados, al control de los monopolios naturales y legales, al de la calidad y eficiencia de los servicios públicos, y a la constitución de asociaciones de consumidores y de usuarios. La legislación establecerá procedimientos eficaces para la prevención y solución de conflictos, y los marcos regulatorios de los servicios públicos de competencia nacional, previendo la necesaria participación de las asociaciones de consumidores y usuarios y de las provincias interesadas, en los organismos de control. Em tradução livre:
} 
No Brasil, houve algumas iniciativas legislativas preliminares à Constituição de 1988, com a edição de normas jurídicas que pontual ou indiretamente significaram defesa do consumidor, ${ }^{28}$ sem, no entanto, identificá-lo como sujeito autônomo de direitos. No âmbito do poder executivo, é de ser registrada especialmente a criação do Conselho Nacional de Defesa do Consumidor, em 1985 . $^{29}$ Entretanto, foi a Constituição de 1988 que deu o grande impulso para o desenvolvimento da proteção ao consumidor, com a culminância da promulgação do código, consubstanciado na Lei 8.078, de 11 de setembro de 1990.

O nosso caminho, portanto, foi vertical, ao contrário do que ocorreu na Europa. No Brasil, da fundamentalidade da proteção ao consumidor posta na Constituição surgiu o CDC. A tarefa foi determinada ao legislador ordinário pelo constituinte no art. 48, do Ato das Disposições Constitucionais Transitórias.

2. A hierarquia constitucional do direito do consumidor e as linhas entre direitos humanos, direitos fundamentais e direitos patrimoniais

A previsão constitucional atribui ao direito do consumidor uma eficácia prevalente sobre as leis ordinárias em geral. Em primeiro lugar, porque integra uma constituição que inova o modelo liberal. A chamada constituição dirigente, ${ }^{30}$ ao contrário de limitar o poder e deixar ao governo a implementação de políticas coerentes com o programa eleitoralmente vencedor, atrela o governo, independentemente de sua ideologia, à realização dos programas constitucionais. Em segundo lugar porque, indo além do dirigismo, a Constituição impõe uma ordem protetiva em benefício do consumidor enquanto sujeito débil. Nem o dirigismo nem o protecionismo constitucional podem ser ignorados, seja pelo legislador, seja pelo intérprete. Em princípio, o destinatário das imposições constitucionais é o legislador, mas também o aplicador da lei - seja ele administrador ou juiz - fica a elas vinculado. Nesse sentido, afirma Canotilho: "Que as imposições constitucionais são, pelo menos, um importante elemento de interpretação, a ter em conta pela administração e jurisdição, parece ser communis opinio”. E acrescenta, depois de considerar problemática a opinião de Esser, segundo a qual o

\footnotetext{
“Art. 42. Os consumidores e usuários de bens e serviços tem directo, na relação de consumo, à proteção de sua saúde, segurança e interesses econômicos; a uma informação adecuada e verdadeira; à liberdade de escolha, e a tratamento equiotativo e digno. As autoridades providenciarlo à proteção desses directos, à educação para o consumo, à defesa da concorrência conttra toda forma de distorção dos mercados, ao controle dos monopólios naturais e legais, à qualidade e eficiencia dos serviços públicos, e à constituição de associações de consumidores e de usuários. A legislação estabelecerá procedimentos eficaces para a prevenção e solução de conflitos, e os marcos regulatórios dos serviços públicos de competência nacional, prevendo a necesaria participação das associações de consumidores e usuários e das provincias interesadas, nos organismos de controle”.

${ }^{28}$ Para uma resenha ampla e possivelmente completa das leis e regulamentos direta ou indiretamente protetivos do consumidor editados até 1983, v.: BRASIL. Relações de consumo. 2. ed. MIC/Conselho de Desenvolvimento Comercial e Fundação Petrônio Portella, 1983, 4 v (Coleção textos legais, 8), trabalho coordenado por Luiz Amaral.

${ }^{29}$ V. OLIVEIRA, Amanda Flávio de. O Sistema Nacional de Defesa do Consumidor: histórico. Revista de Direito do Consumidor, ${ }^{\circ}$ 44, out.-dez. 2002, p. 97-105.

${ }^{30}$ Definir o que seja constituição dirigente exige uma pré-compreensão do que seja constituição: simples instrumento de governo, definidor de competências e regulador de processos, ou um plano normativomaterial global do Estado e da sociedade? (CANOTILHO, José Joaquim Gomes. Constituição dirigente e vinculação do legislador. Coimbra Editora, 1994, p. 12).
} 
juiz pode criar direito material a partir das normas constitucionais: “(...) é admissível a aplicação imediata dos princípios constitucionais, sempre que isso possa ser feito sem mediação legislativa e, neste caso, pode dizer-se que as imposições constitucionais se dirigem também ao juiz e à administração.”31

O Tribunal Constitucional português, segundo relata António Pinto Monteiro, em duas decisões assegurou a vigência dos direitos dos consumidores contra leis que os desconsideravam. No primeiro caso, o estatuto dos correios criava isenção de responsabilidade por lucros cessantes; no segundo, a favorecida era a estrada de ferro por danos causados aos passageiros por atrasos, supressão de comboios ou perdas de conexão. ${ }^{32}$

A constitucionalização da defesa do consumidor é corolário da afirmação da dignidade da pessoa humana como princípio que passa a condensar uma espécie de direito constitucional da pessoa, tal a importância que essa tutela adquiriu, como explica Bruno Miragem. A incorporação constitucional de relações jurídicas antes disciplinadas pelo direito civil determina uma alteração qualitativa do status dos direitos desses sujeitos (consumidores, crianças e adolescentes, idosos etc), que passam a ser preferenciais em relação a direitos de matriz infraconstitucional, exigindo providências concretas para a sua realização. ${ }^{33}$ Os direitos dos consumidores, segundo José Alcebíades de Oliveira Júnior, "não devem ser mais vistos preponderantemente como um problema social ou de política pública, mas de dignidade da pessoa humana”. ${ }^{34}$

A vinculação da proteção ao consumidor com a dignidade da pessoa humana, colocada esta, como está, no topo das normas constitucionais, assegura ao direito do consumidor a condição de direito materialmente constitucional. A fundamentalidade formal é facilmente verificável pelas disposições constitucionais já referidas (art. 5º, XXXII e art. 170, V), normas que em si seriam diretamente aplicáveis - não fora a existência do CDC - e cuja reforma exige o procedimento agravado próprio às modificações do texto constitucional, ${ }^{35}$ sendo que a norma do art. $5^{\circ}$, XXXII é insuscetível de supressão por se tratar de cláusula pétrea, ${ }^{36}$ impondo ao Estado uma proibição de retrocesso na proteção já outorgada ao consumidor. ${ }^{37}$

31 CANOTILHO, José Joaquim Gomes. Constituição dirigente e vinculação do legislador. Coimbra Editora, 1994, p. 295. No mesmo sentido, defendendo a eficácia social prima facie dos direitos fundamentais, nos sentidos vertical (entre Estado e particulares) e horizontal (entre particulares), assim como de modo direto e indireto: SARLET, Ingo Wolfgang. Direitos fundamentais sociais, mínimo existencial e direito privado. Revista de Direito do Consumidor, vol. 61, jan.-mar. 2007, p. 90-125 (111).

${ }^{32}$ MONTEIRO, António Pinto. Breve nótula sobre a proteção do consumidor na jurisprudência constitucional portuguesa. In: Direitos fundamentais e direito privado: uma perspectiva de direito comparado. Organizadores: António Pinto Monteiro, Jörg Neuner e Ingo Sarlet. Coimbra: Almedina: 2007, p. 293-304. ${ }^{33}$ MIRAGEM, Bruno. Direito do consumidor. São Paulo: Revista dos Tribunais, 2008, p. 34.

${ }^{34}$ OLIVEIRA JÚNIOR, José Alcebíades de. Casos difíceis, direitos dos consumidores e direitos fundamentais: considerações sobre um caso exemplar. Revista de Direito do Consumidor, vol. 59, jul.-set; 2006, p. 62-77 (77).

${ }^{35}$ Sobre a fundamentalidade formal e material dos direitos fundamentais: SARLET Ingo W. A eficácia dos direitos fundamentais. 6. ed. Porto Alegre: Livraria do Advogado, 2006, p. 88-92).

${ }^{36}$ Assim: Claudia Lima Marques, aludindo ao art. 60, § $4^{\circ}$, IV, que retira da possibilidade de apreciação emenda à Constituição tendente a abolir os direitos e garantias individuais. In: BENJAMIN, Antônio H. V.; MARQUES, Claudia L.; BESSA, Leonardo R. Manual de direito do consumidor. São Paulo: Revista dos Tribunais, 2007, p. 26.

${ }^{37}$ MIRAGEM, Bruno. Direito do consumidor. São Paulo: Revista dos Tribunais, 2008, p. 36. 
Sobre a defesa como consumidor como corolário da dignidade da pessoa humana na Constituição, assim se expressa o insuspeito administrativista Diogo de Figueiredo Moreira Neto:

A dignidade da pessoa humana, princípio fundamental da Constituição (art. $1^{\circ}, \mathrm{III}$ ), desdobra-se e expressa-se, no campo econômico, com o princípio geral da defesa do consumidor (art. 170, V), reiterando, como linha de atuação do Estado nessa matéria fronteiriça entre o direito público e o privado, o que também se explicita como direito fundamental (art. 5, XXXII), como direito do contribuinte (art. 150, $\S 5^{\circ}$ ) e como direito do usuário de serviços públicos (art. 175, parágrafo único, II). ${ }^{38}$

Além de figurar na Constituição, o que por si só lhe atribuiria a eficácia própria das normas constitucionais - com aplicabilidade direta e imediata no art. $5^{\circ}$, XXXII, na qualidade de direito individual, e com aplicabilidade limitada como princípio da ordem constitucional no art. $170, \mathrm{~V}^{39}$-, a proteção ao consumidor constitui o substrato de um direito humano, colocado entre os direitos fundamentais da nossa Carta Magna.

A diferença conceitual entre direitos humanos e direitos fundamentais é explicada por Ingo Sarlet, aderindo à opinião de que os primeiros adquirem a segunda denominação ao serem reconhecidos e positivados na esfera do direito constitucional de um país. A expressão direitos humanos é usada, porém, nos documentos internacionais, uma vez que se refere às posições jurídicas reconhecidas como inerentes ao ser humano, independentemente da sua vinculação a uma ordem constitucional positiva. Acrescenta Sarlet não haver coincidência entre direitos humanos e direto natural, haja vista a dimensão histórica e relativa dos direitos humanos. ${ }^{40}$ Nessa diferença permeia uma questão de eficácia. Como diz Alexy, “os direitos humanos só podem desenvolver seu pleno vigor quando se os garante através de normas de direito positivo", e são incorporados como obrigatórios no catálogo de direitos fundamentais de uma constituição. ${ }^{41} \mathrm{O}$ direito do consumidor encontra fundamentação ambivalente, pois tanto é tratado pelos organismos supranacionais quanto é reconhecido na Constituição Federal entre os direitos fundamentais (art. 5º XXXII: é dever do Estado promover a defesa do consumidor; art. 170, V: a defesa do consumidor é um dos princípios a serem observados na organização da economia).

Luigi Ferrajoli concebe os direitos humanos como uma classe primária de direitos da pessoa (direitos da personalidade), compreendendo o direito à vida e à integridade, a liberdade pessoal, a liberdade de consciência e de manifestação do

\footnotetext{
${ }^{38}$ MOREIRA NETO, Diogo de Figueiredo. Curso de direito administrativo: parte introdutória, parte geral e parte especial. Rio de Janeiro: Forense, 2005, p. 486.

${ }^{39}$ SILVA, José Afonso da. Curso de direito constitucional positivo. 27. ed. São Paulo: Malheiros, 2006, p. 140 e 142.

${ }^{40}$ SARLET, Ingo W. A eficácia dos direitos fundamentais. 6. ed. Porto Alegre: Livraria do Advogado, 2066, p. 35-36.

${ }^{41}$ ALEXY, Robert. Teoria del discurso y derechos humanos. Tradução para o espanhol de Luis Villar Borda. Bogotá: Universidad Externado de Colômbia, 2005, p. 93.
} 
pensamento, o direito à saúde e à educação e as garantias penais e processuais, mas entende-os como direitos fundamentais tout court. Para ele, são fundamentais todos os direitos subjetivos que correspondem universalmente a todos os seres humanos. Esses direitos podem estar sancionados positivamente nas leis e nas constituições, mas prescindem dessa condição. E adstringe o conceito de direitos humanos a "todas as pessoas físicas enquanto tais, enquanto cidadãos ou enquanto capazes de agir". A vocação dos direitos fundamentais para as pessoas físicas é significativa para a limitação extensiva do Código de Defesa do Consumidor em favor das pessoas jurídicas, como será abordado adiante.

Afirma ainda Ferrajoli que os direitos fundamentais não olham a natureza dos interesses e das necessidades em causa, citando como exemplos a liberdade pessoal, a liberdade de pensamento, os direitos políticos, os direitos sociais e similares. Deveriam ser, por outro lado, rechaçados como direitos fundamentais todos os que fossem passíveis de alienação, como aconteceria numa sociedade totalmente mercantilista, porque esses direitos perderiam a sua universalidade. ${ }^{42}$

Em crítica de muita pertinência, Ferrajoli assinala que o conceito uniformizador dos direitos subjetivos ocultou durante muito tempo as diferenças substanciais entre direitos fundamentais e direitos patrimoniais: aqueles são inclusivos, universais e indisponíveis; estes são exclusivos, singulares e disponíveis. Enquanto os direitos fundamentais, como a liberdade, o direito à vida e mesmo os direitos civis como o direito à propriedade, favorecem indistintamente a todos, e ninguém deles pode ser privado, os direitos patrimoniais aquinhoam de modo distinto e singular cada um dos seus titulares. ${ }^{43}$ Na mesma linha de raciocínio, Barzotto afirma que "a doutrina dos direitos humanos é antitética à doutrina liberal dos direitos do homem”, ${ }^{44}$ entendidos estes como direitos atribuídos singularmente a cada indivíduo.

\section{A proteção ao consumidor como direito subjetivo público}

É importante destacar que a proteção ao consumidor se faz a um sujeito de direitos e não ao ato de consumo, como é usado em alguns outros países. No Brasil, Antônio Herman Benjamin suscitou a questão e desde logo justificou a opção pela funcionalidade de “direito do consumidor", que traduz o resguardo dos interesses da pessoa dos consumidores, excluindo, por outro lado, aspectos que dizem respeito ao consumo apenas em sentido amplo, como o combate aos monopólios. ${ }^{45}$ Em Portugal, a doutrina referia-se a "direito do consumo", não obstante e auspiciosamente, com o aplauso de Antônio Pinto Monteiro, tenha vingado no plano legislativo a expressão “direito do consumidor”, assim na Constituição portuguesa (artigos 60, 81 e 99),

42 FERRAJOLI, Luigi. Derechos y garantias: la ley del más débil. Tradução para o espanhol de Perfecto Andrés Ibáñez e Andréa Greppi. 2. ed. Madrid: Editorial Trotta, 2001, p. 37-41.

${ }^{43}$ FERRAJOLI, Luigi. Ob. cit., p. 46.

${ }^{44}$ BARZOTTO, Luis Fernando. Os direitos humanos como direitos subjetivos: da dogmática jurídica à ética. In: Jurisdição e direitos fundamentais: anuário 2004-2005. Coord.: Ingo W. Sarlet. Porto Alegre: Escola Superior da Magistratura / Livraria do Advogado, 2006, p. 241.

${ }^{45}$ BENJAMIN, Antônio Herman. O Direito do Consumidor. Revista dos Tribunais, vol. 670, ago. 1991, p. 49-61 (50). No mesmo sentido: CAVALIEIRI FILHO, Sérgio. Programa de direito do consumidor. São Paulo: Atlas, 2008, p. 8. 
como na Lei de Defesa do Consumidor, seja a de 1981, seja a de $1996 .{ }^{46}$ A designação da disciplina destaca o sujeito protegido também na Alemanha (Verbrauchersdchtutz). Na França, persiste a nomenclatura equivocada droit de la consommation, assim como na Bélgica e na Itália, no plano legal (Codice del consumo), embora a doutrina trate do diritto del consumatore. Na Espanha prevalece, tanto na lei quanto na doutrina, derecho del consumidor. No direito saxônico de modo geral e no norte-americano fala-se, corretamente, em consumer law. Na nossa vizinhança, prevalece defensa del consumidor. Assim é nas leis da Argentina $^{47}$ e do Paraguai. ${ }^{48}$ No Uruguai, a lei menciona as relações de consumo. ${ }^{49}$

A nomenclatura não é questão secundária ou meramente formal porque, ao identificar o ramo jurídico a partir do sujeito protegido, remete à dignidade da pessoa ao invés de circunscrever-se ao objeto de uma ação. ${ }^{50} \mathrm{O}$ ato de consumo é impessoal e sugere uma relação jurídica despersonalizada, tal como uma compra e venda ou qualquer outro contrato, tipificado pela operação econômica e não pelos sujeitos. O direito do consumidor, ao contrário, adquire identidade jurídica e se justifica como tipo em virtude da relação jurídica estabelecida entre sujeitos distintos: um o fornecedor - que realiza atividade lucrativa e para quem, com efeito, a operação econômica é o mais importante; outro - o consumidor - que procura suprir as suas necessidades básicas, apresentando-se com a nota da vulnerabilidade, que justifica a proteção jurídica especial. O efetivo suprimento dessas necessidades em condições de dignidade humana é o verdadeiro escopo do direito do consumidor. Portanto, proteção ao consumidor e dignidade da pessoa humana são inseparáveis. Ou, nos dizeres de Geisa de Assis Rodrigues: "A mais importante mensagem da norma constitucional [referindo-se em conjunto aos artigos $5^{\circ}$, XXXII, 170, V, cf, e 48, $\mathrm{ADCT}$ ] é a necessidade do novo código [o CDC] respeitar a importância das pessoas na economia de mercado". 51

São três as correntes de opinião acerca da natureza jurídica dos direitos humanos. A primeira faz depender a juridicidade dos direitos humanos da sua previsão no ordenamento jurídico positivo. Se não há previsão normativa, não há o que se chama direito. Nessa posição encontra-se, por exemplo, Norberto Bobbio. A segunda corrente entende que os direitos humanos são sempre direitos subjetivos, conforme

\footnotetext{
46 MONTEIRO, Antônio Pinto. Sobre o direito do consumidor em Portugal. Disponível em http://www.apdi.pt/APDI/DOUTRINA/sobre\%20o\%20direito\%20do\%20consumidor\%20em\%20portugalEDCn\%C2\%BA4.pdf. Acesso em 21 jul. 2009.

${ }^{47}$ Lei $24.240 / 93$, modificada pela Lei 24.999/98. V. texto integral desta última in: Revista de Direito do Consumidor, $\mathrm{n}^{\circ}$ 27, jul.-set. 1998, p. 139-140.

${ }^{48}$ Ley 1.334/98 de defensa del consumidor y del usuario. V. texto integral in: Revista de Direito do Consumidor, $\mathrm{n}^{0}$ 30, abr.-jun 1999, p. 247-255.

${ }^{49}$ Ley 17.189: dictanse normas relativas a lãs relaciones de consumo. V. texto integral in: Revista de Direito do Consumidor, ${ }^{\circ}$ 33, jan.-mar. 2000, p. 262-270.

${ }^{50}$ Daí a correta fundamentação do dano moral nas relações de consumo como ofensa à dignidade do consumidor. Nesse sentido: BOLSON, Simone Hegele. O princípio da dignidade da pessoa humana, relações de consumo e o dano moral ao consumidor. Revista de Direito do Consumidor, ${ }^{\circ}$ 46, abr.-jun. 2003, p. 265-291.

${ }^{51}$ RODRIGUES, Geisa de Assis. A proteção ao consumidor como um direito fundamental. Revista de Direito do Consumidor, vol. 58, abr.-jun. 2006, p. 75-97 (80).
} 
estes são tradicionalmente entendidos na dogmática jurídica, sendo, portanto, passíveis de exigência em juízo. E a terceira, defendida por Luis Fernando Barzotto, toma a dignidade da pessoa humana como referência de valor para definir o que deve ter validade como direito positivo. Para Barzotto, somente a ética tomista pode propor um conceito de direito subjetivo capaz de apreender os direitos humanos, libertando-os dos limites estreitos da dogmática jurídica. ${ }^{52}$

De acordo com a ética tomista, e levando em consideração que, em princípio, a todo direito corresponde um dever, todo ser humano, por ser titular dos direitos inerentes à sua condição humana, transforma qualquer outro ser humano com quem se relaciona (co-humano) em titular de deveres, adstrito a respeitar os direitos alheios. ${ }^{53}$

Na estratificação estatal e na representação política que assume, o Estado é titular dos deveres próprios da comunidade de co-humanos que tem no consumidor o titular dos correspectivos direitos. ${ }^{54}$

O consumidor é um conceito de validade universal - recorde-se a sempre citada alocução de John Kennedy, afirmando que "todos nós somos consumidores"55 -, pois todos os seres humanas são igualmente contingentes nas suas necessidades existenciais, ainda que elas possam variar de indivíduo a indivíduo em graus mais afastados das condições básicas de sobrevivência.

\section{A defesa do consumidor como princípio da ordem econômica}

A inserção da defesa do consumidor entre os princípios da ordem econômica provocou uma reacomodação dos fatores tradicionais que lhe serviam de base: o direito de propriedade e a livre iniciativa. Ambos foram relativizados. O primeiro, mais especialmente pela função social da propriedade e o segundo, especificamente, pela defesa do consumidor. Como afirma Bobbio: "Não se pode afirmar um novo direito em favor de uma categoria de pessoas sem suprimir algum velho direito, do qual se beneficiavam outras categorias de pessoas". ${ }^{56}$

Quem se beneficiava da ausência da defesa do consumidor eram os agentes econômicos em geral, que por muito tempo foram regidos quase exclusivamente pela liberdade contratual. Propalava-se a falsa idéia de que as preferências dos consumidores eram determinantes da produção, omitindo-se a influência decisiva do marketing e de um dos seus mais poderosos instrumentos - a publicidade - como controladores

52 BARZOTTO, Luis Fernando. Os direitos humanos como direitos subjetivos: da dogmática jurídica à ética. In: Jurisdição e direitos fundamentais: anuário 2004-2005. Coord.: Ingo W. Sarlet. Porto Alegre: Escola Superior da Magistratura / Livraria do Advogado, 2006, p. 241-244.

${ }^{53}$ BARZOTTO, Ob. cit., p. 251.

${ }^{54}$ Nem sempre o Estado responde aos seus deveres, como registra José Alcebíades de Oliveira Júnior: “(...) o que nos faz cidadãos é a nossa capacidade de consumo, e não a atenção que o Estado deveria ter conosco (...)” (OLIVEIRA JÚNIOR, José Alcebíades de. Casos difíceis, direitos dos consumidores e direitos fundamentais: considerações sobre um caso exemplar. Revista de Direito do Consumidor, vol. 59, jul.-set; 2006, p. 62-77 (66).

${ }_{55}$ Special message on protecting consumers interests. Statement read by President John F. Kennedy. Thursday, 15 march 1962. Dísponível em: http://www.consumersinternational.org/shared_asp_files/ uploadedfiles/4F4F223B-73E3-4F19-85C6-E705AD922376_kennedy.pdf. Acesso em 21 ago. 2009.

${ }_{56}$ BOBBIO, Norberto. A era dos direitos. Trad. Carlos Nelson Coutinho. Nova edição. Rio de Janeiro: Elsevier, 2004, p. 40. 
remotos de tais preferências. ${ }^{57} \mathrm{O}$ dirigismo, que sobreveio em meados do século $\mathrm{XX}$, foi recebido como um atentado contra a liberdade. ${ }^{58}$ Entretanto, as intervenções do Estado na economia decorreram naturalmente do advento da produção em massa e da crise do mercado como espaço de escolhas voluntárias. ${ }^{59}$

É fato que a introdução da defesa do consumidor no contexto da ordem econômica não lhe assegura supremacia, mas ela passa a participar de um "jogo concertado" com os co-princípios do art. $170,{ }^{60}$ interagindo no permanente processo de redefinição e reconstrução da chamada identidade constitucional. ${ }^{61} \mathrm{E}$ já agora a proteção ao consumidor não se faz dispersamente, como à época do dirigismo estatal, mas sim de modo sistemático, em favor de um sujeito concreto, seja qual for a natureza da relação jurídica de que participe. ${ }^{62}$

O “jogo concertado” está presente também no art. $4^{\circ}$, inciso III, ao referir que deve haver harmonia de interesses nas relações de consumo e compatibilidade entre a proteção ao consumidor e o desenvolvimento econômico e tecnológico, de modo a viabilizar os princípios da ordem econômica.

Em perfeita consonância com esse entendimento, Miguel Reale afirma que a díade livre concorrência e defesa do consumidor dá o efetivo sentido ideológico da Constituição que, a seu juízo, é inequivocamente social-liberal, caracterizado por um contínuo balanceamento de valores. ${ }^{63}$

O papel reservado à defesa do consumidor, como alude Ronaldo Porto Macedo Júnior, é legitimador e transformador da ordem de mercado dominante, influenciando as racionalidades jurídicas que podem fundamentar o direito contemporâneo. ${ }^{64}$ Ainda:

\footnotetext{
${ }^{57}$ Sobre a influência da publicidade no consumo: PASQUALOTTO, Adalberto. Os efeitos obrigacionais da publicidade no Código de Defesa do Consumidor. São Paulo, Revista dos Tribunais, 1997. A idéia do consumidor como "rei do mercado" foi brilhantemente rebatida em: GALBRAITH, John Kenneth. A cultura do contentamento. Trad. Carlos Afonso Malferrari. São Paulo: Pioneira, 1992, p. 83.

${ }^{58}$ FIN-LANGER, Laurence. L'équilibre conractuel. Paris: L.G.D.J., 2002, p. 49.

${ }^{59}$ MACEDO JÚNIOR, Ronaldo Porto. Contratos relacionais e a defesa do consumidor. 2. ed. São Paulo: Revista dos Tribunais, 2007, p. 47.

${ }^{60}$ MENDES, Gilmar Ferreira; COELHO, Inocêncio Mártires; BRANCO, Paulo Gustavo Gonet. Curso de direito constitucional. 4. ed. São Paulo: Saraiva, 2009, p. 1.415.

${ }^{61}$ SARLET, Ingo Wolfgang. Direitos fundamentais sociais, mínimo existencial e direito privado. Revista de Direito do Consumidor, vol. 61, jan.-mar. 2007, p. 90-125 (92).

62 ...Ainda que a inserção constitucional possa ter sido facilitada por interesses de outros atores, que não diretamente os consumidores, voltados para a derrubada de algumas barreiras de comércio que a bandeira da defesa do consumidor facilitaria. Assim: MACEDO JÚNIOR, Ronaldo Porto. Contratos relacionais e a defesa do consumidor. 2. ed. São Paulo: Revista dos Tribunais, 2007, p. 219, que também registra a diferença de agendas políticas entre diferentes grupos de defesa do consumidor (p. 220).

63 REALE, Miguel. O Estado Democrático de Direito e o conflito das ideologias. São Paulo: Saraiva, 1998, p. 45-47. José Afonso da Silva, comentando a afirmativa de Reale e opondo-se parcialmente, concorda que a livre iniciativa deve ser harmonizada com os interesses coletivos dos consumidores, mas lembra que a ordem econômica compreende, além desses princípios, todos os demais elencados no art. 170 (SILVA, José Afonso da. Princípios constitucionais fundamentais. In: 20 anos da Constituição cidadã. Cadernos Adenauer IX. Rio de Janeiro: Fundação Konrad Adenauer, 2008, p. 9-19 (14).

${ }^{64}$ MACEDO JÚNIOR, Ronaldo Porto. Contratos relacionais e a defesa do consumidor. 2. ed. São Paulo: Revista dos Tribunais, 2007, p. 225.
} 
A correção do mercado e a introdução de princípios contratuais estranhos à concepção clássica de liberdade contratual (...) são também fundamentadas em critérios éticos e vinculados a uma racionalidade moral, a uma concepção de justiça, e a uma idéia a respeito da forma possível do mercado, de seus fins e de seus objetivos. ${ }^{65}$

Isso projeta metafisicamente a defesa do consumidor como definidora da ordem econômica.

Vale lembrar Rawls: "O sistema econômico não é apenas um dispositivo institucional para satisfazer desejos e necessidades existentes, mas também um modo de criar e moldar necessidades no futuro”. Portanto, a escolha das instituições responsáveis pelos arranjos econômicos não deve ter fundamento apenas em considerações de eficiência ou puramente econômicas, mas também morais e políticas. ${ }^{66}$

As relações do direito com a moral deixaram de ser de estranhamento quando pensadores importantes como Alexy, Hart, Dworkin e Bobbio, numa segunda fase de sua obra, passaram a se preocupar com as repercussões das decisões jurídicas, vendo o direito como um sistema aberto, que eventualmente vai buscar sua fundamentação além do próprio direito. ${ }^{67}$

\section{PROJEÇÕES INFRACONSTITUCIONAIS DO DIREITO DO CONSUMIDOR}

A hierarquia constitucional da defesa do consumidor projeta-se na legislação infraconstitucional, especialmente no Código de Defesa do Consumidor, ao qual incumbem dois papéis: descortinar os amplos horizontes da sua missão específica e ao mesmo tempo delimitar o seu campo de incidência normativa, considerando a sua natureza protetiva e especial.

\section{Consumidor \\ 1. $\mathrm{O}$ art. $1^{\circ}$ e a expressão da fundamentalidade do Código de Defesa do \\ Dispõe literalmente a norma de entrada do Código de Defesa do Consumidor:}

Art. $1^{\circ} \mathrm{O}$ presente código estabelece normas de proteção e defesa do consumidor, de ordem pública e interesse social, nos termos dos arts. $5^{\circ}$, inciso XXXII, 170, inciso V, da Constituição Federal e art. 48 de suas Disposições Transitórias.

Como normas de ordem pública, as disposições legislativas do CDC não constituem exceção à ordem econômica em que estão inseridas, constituindo um instrumento técnico concorrente com o direito civil clássico. ${ }^{68}$

\footnotetext{
${ }^{65}$ MACEDO JÚNIOR, Ob. cit., p. 231.

${ }^{66}$ RAWLS, John. Uma teoria da justiça. 3. ed. Trad. de Jussara Simões. São Paulo: Martins Fontes, 2008, p. 323.

${ }^{67}$ OLIVEIRA JÚNIOR, José Alcebíades de. Casos difíceis, direitos dos consumidores e direitos fundamentais: considerações sobre um caso exemplar. Revista de Direito do Consumidor, vol. 59, jul.-set; 2006, p. 62-77 (63).

${ }^{68}$ GRAU, Eros Roberto. A ordem econômica na Constituição de 1988: interpretação e crítica. 11. ed. São Paulo: Revista dos Tribunais, 2006, p. 62.
} 
Entretanto, dele distinguem-se radicalmente, porque seria inútil deixar aos próprios consumidores, ainda que organizados coletivamente, a estratégia de negociar com as empresas as condições de contratação que devessem ser observadas no plano individual. Roppo lembra que os consumidores, diversamente dos trabalhadores, não constituem uma classe, tendo interesses marcadamente heterogêneos. ${ }^{69}$ As normas do CDC atendem, assim, ao interesse social, contrapondo-se ao dogma da autonomia privada ${ }^{70} \mathrm{e}$ instaurando a função social do contrato em antecipação ao Código Civil de 2002.

Fernando Costa de Azevedo lembra outra repercussão importante da pertinência do CDC à ordem pública: é que o juiz sempre poderá conhecer, nos processos, de matéria de interesse dos consumidores, independentemente de argüição. ${ }^{71}$ A jurisprudência do STJ, entretanto, contrariando essa lógica, tem decidido que cláusulas contratuais abusivas não podem ser examinadas de ofício. ${ }^{72}$

O texto do art. $1^{\circ}$ remete diretamente às disposições constitucionais que dão à proteção ao consumidor no Brasil o seu caráter formal de direito fundamental, independentemente da dimensão material. Uma vez que as normas do Código são de ordem pública e interesse social, tornam-se indisponíveis. A indisponibilidade não é constituída pelo art. $1^{\circ}$, é apenas declarada, uma vez que ela decorre da própria natureza de todos os direitos fundamentais. Segundo Ferrajoli, a indisponibilidade significa a imunidade dos direitos fundamentais às decisões da política e do mercado. ${ }^{73}$

As conseqüências que se projetam da indisponibilidade da proteção ao consumidor em virtude da sua natureza de direito fundamental são da maior importância.

No campo da política, significa que o Estado é obrigado a cumprir as prestações e deveres relativos à defesa do consumidor. A fundamentalidade material constitucional de um direito dota-o de tal relevância e essencialidade que exige uma normatividade reforçada, excluindo-o da disponibilidade dos poderes constituídos. ${ }^{74}$ Nesse passo, os de veres do Estado para com os consumidores não se esgotaram com a edição do Código. Eles permanecem em vários aspectos, como, por exemplo, na formulação e execução da Política Nacional das Relações de Consumo, de que trata o art. 4º CDC. Isso quanto às prestações positivas. No tocante às negativas, o Estado é obrigado a impedir e a reprimir as infrações contra as relações de consumo - o que justifica a existência de disposições administrativas e penais. Adiante serão tratadas com mais detalhes a Política Nacional das Relações de Consumo e a repressão às infrações.

${ }^{69}$ ROPPO, Enzo. O contrato. Trad. Ana Coimbra e M. Januário. Gomes. Coimbra: Almedina, 1988, p. 328. No mesmo sentido: MACEDO JÚNIOR, Ronaldo Porto. Contratos relacionais e a defesa do consumidor. 2. ed. São Paulo: Revista dos Tribunais, 2007, p. 216.

${ }_{70}$ MARQUES, Claudia Lima; BENJAMIN, Antônio Herman; MIRAGEM, Bruno. Comentários ao Código de Defesa do Consumidor. São Paulo: Revista dos Tribunais, 2004, p. 55.

${ }^{71}$ AZEVEDO, Fernando Costa de. Uma introdução ao direito brasileiro do consumidor. Revista de Direito do Consumidor, vol. 69, jan.-mar. 2009, p. 32-86 (57).

${ }^{72}$ Assim: STJ, EDCl no REsp 1005046, 4 $4^{\text {a }}$ Turma, Rel. Min. João Otávio de Noronha, 10.03.2009, unânime; STJ, REsp 962915, $3^{\mathrm{a}}$ Turma, Rel ${ }^{\mathrm{a}}$ Min $^{\mathrm{a}}$ Nancy Andrghi, 09.12.2008, unânime.

${ }^{73}$ FERRAJOLI, Luigi. Derechos y garantias: la ley del más débil. Tradução para o espanhol de Perfecto Andrés Ibáñez e Andréa Greppi. 2. ed. Madrid: Editorial Trotta, 2001, p. 47.

${ }^{74}$ SARLET, Ingo Wolfgang. Direitos fundamentais sociais, mínimo existencial e direito privado. Revista de Direito do Consumidor, vol. 61, jan.-mar. 2007, p. 90-125 (98). 
Ainda no pertinente à subordinação do Estado ao cumprimento dos seus deveres fundamentais para com os consumidores, constitui um capítulo à parte, a merecer um estudo específico, o antagonismo que se estabeleceu entre a atuação das agências de regulação e a defesa do consumidor, em geral desconsiderada ou subestimada.

A atividade das agências deve ser harmonizada com a defesa do consumidor. Nesse sentido expressou-se a Ministra Eliana Calmon, ao proclamar, em julgamento, que "não existe incompatibilidade entre o sistema de regulação dos serviços públicos de titularidade do estado prestados de forma indireta e o de proteção e defesa do consumidor, havendo, ao contrário, perfeita harmonia entre ambos". ${ }^{75}$ Tratava-se de desavença sobre a possibilidade jurídica de cobrança da assinatura mensal básica pelas empresas de telefonia fixa, prevista pela Lei Geral de Concessões - Lei 8.987/95, e que foi mantida na decisão.

O CDC não pode ser ignorado em vista do seu caráter principiológico. Não é lei geral, nem especial, pois estabelece os fundamentos da relação jurídica de consumo, que se caracteriza mesmo em setores particulares como o securitário, o bancário etc, ${ }^{76}$ inclusive nos serviços públicos regulados por agências. A correta interpretação das relações jurídicas que apresentam diversidade de fontes legislativas deve ser feita conforme o diálogo das fontes, proposto no Brasil por Cláudia Lima Marques, um modelo hermenêutico não excludente, que supera as antinomias pela sistematização coerente, por complementaridade e subsidiariedade ou por influências recíprocas das leis em questão. ${ }^{77}$

O mercado, por outro lado, não pode solapar as normas de conduta relativas à defesa dos consumidores como sujeitos débeis das relações de consumo. Sabe-se, contudo, que nem sempre o mercado cumpre as normas jurídicas obrigatórias. Como faz ver Max Weber, o trato jurídico e o trato econômico formulam questões inteiramente heterogêneas. O direito propõe uma ordem ideal, sem contradição lógica interna, com pretensão a determinar a ação. Os agentes econômicos, porém, movimentam-se no mundo real e orientam-se conforme o seu efetivo poder de disposição sobre bens e serviços, produzindo consensos que se formam no ponto de equilíbrio dos interesses em jogo. ${ }^{78}$ Em outras palavras, o mercado movimenta-se pelo fenômeno específico do regateio. ${ }^{79}$

Nem sempre há coincidência entre a conduta ideal prevista na norma jurídica e a ação real dos agentes econômicos. Aliás, há uma implícita contradição. É no mercado que o consumidor procura os bens e serviços aptos à satisfação de suas necessidades vitais - e o mercado, como frisa Max Weber, é constituído pela "relação vital prática

\footnotetext{
${ }^{75}$ Resp 1007703-RS e Ag Rg no Ag 1034962, 2 2a Turma, Relatora Min. Eliana Calmon, 21.08.2008, unânimes.

${ }^{76}$ NERY JÚNIOR, Nelson. A defesa do consumidor no Brasil. Revista de Direito Privado n 18 , abr.-jun. 2004, p. 218-297 (222).

${ }^{77}$ MARQUES, Claudia Lima. Tres tipos de diálogos entre o Código de Defesa do Consumidor e o Código Civil de 2002: superação das antinomias pelo diálogo das fontes. In: PFEIFFER, Roberto; PASQUALOTTO, Adalberto (org.). Código de Defesa do Consumidor e o Código Civil de 2002: convergências e assimetrias. São Paulo: Revista dos Tribunais, 2005.

${ }^{78}$ WEBER, Max. Economia e sociedade. Vol. 1. Tradução de Regis Barbosa e Karen Elsabe Barbosa. 3. ed. Brasília: Editora Universidade de Brasília, 2000, p. 209.

${ }^{79}$ WEBER, Ob. cit., p. 419.
} 
mais impessoal que pode existir entre os homens". ${ }^{80}$ Chocam-se a dignidade do consumidor como pessoa humana e sujeito de direitos humanos, necessitado de atendimento para demandas vitais, com a impessoalidade e mesmo a hostilidade das relações econômicas. Como já frisava Kant: "No reino dos fins tudo tem um preço ou uma dignidade. Quando uma coisa tem um preço, pode-se por em vez dela qualquer outra coisa como equivalente; mas quando uma coisa está acima de todo o preço, e portanto não permite equivalente, então ela tem dignidade". ${ }^{8}$

O mercado, segundo Max Weber, "é originalmente uma relação associativa com não-companheiros, isto é, inimigos". 82 Daí que, quando "o mercado é deixado à sua legalidade intrínseca, leva apenas em consideração a coisa, não a pessoa, inexistindo deveres de fraternidade e devoção ou qualquer das relações humanas originárias sustentadas pelas comunidades pessoais". ${ }^{83}$

Em precisa descrição etnográfica das relações de consumo, Ciméa Bevilacqua assinala que a assimetria entre fornecedor e consumidor, que é inerente às suas posições, tanto em termos lógicos quanto no plano empírico, não impede as trocas entre eles, porque há uma equivalência momentânea que envolve os objetos trocados e os próprios trocadores. Trata-se, porém, de um equilíbrio precário, pendente entre uma desigualdade real e uma igualdade postulada, que confere às relações de consumo um caráter potencialmente agonístico e nas quais o conflito é sempre uma iminência. E quando ele ocorre, repõe-se imediatamente a assimetria que a precariedade da equivalência escamoteava, pois os meios de salvaguarda dos interesses do fornecedor são muito mais poderosos que os do consumidor. ${ }^{84}$

São essas razões que justificam a intervenção do Estado, com a finalidade de compensar as relações desiguais, que põem em evidência a vulnerabilidade da parte mais fraca.

O direito do consumidor coloca-se, assim, na intersecção entre o direito e a economia. Compete, entretanto, esclarecer qual é a sua posição epistemológica.

2. Epistemologia, autonomia científica e codificação do direito do consumidor

Já se disse que o direito do consumidor é um capítulo do direito econômico, afirmação que sugere uma certa subordinação, apesar de autor da afirmação, Fábio Konder Comparato, ao tempo em que a fez, ter pregado a necessidade de proteção ao consumidor, que então era inexistente. ${ }^{85}$

Compreende-se o direito econômico como o estudo da intervenção do Estado na economia e das conseqüentes relações entre entes públicos e privados. ${ }^{86}$

${ }^{80}$ WEBER, Ob. cit., p. 420.

81 KANT, Immanuel. Fundamentação da metafísica dos costumes. Traduzida do alemão por Paulo Quintela. Lisboa: Edições 70, 2005, p. 77.

${ }^{82}$ WEBER, Ob. cit., p. 422.

${ }^{83}$ WEBER, Ob. cit., p. 420

${ }^{84}$ BEVILAQUA, Ciméa Barbato. Consumidores e seus direitos: um estudo sobre conflitos no mercado de consumo. São Paulo: Humanitas/NAU, 2008, p. 158.

${ }^{85}$ COMPARATO, Fábio Konder. A proteção do consumidor: importante capítulo do direito econômico. Ensaios e pareceres de direito empresarial. Rio de Janeiro: Forense, 1978, p. 473-499.

${ }^{86}$ MONCADA, Luis S. Cabral de. Direito econômico. 2. ed. Coimbra Editora, 1988, p. 12. Nessa perspectiva, 
Comparato demonstra que o seu surgimento decorre de dois fatos principais: a primeira guerra mundial, que demonstrou ao Estado que uma guerra não é ganha apenas nos campos de batalha, mas também nas usinas, nas fábricas e nos laboratórios, e a crise de 1929, que representou o fim do liberalismo e a nova fase de decidida intervenção estatal na economia. ${ }^{87}$ Assim, para Comparato, o direito econômico constitui-se do conjunto das técnicas jurídicas de que se serve o Estado para a realização da sua política econômica. ${ }^{88}$

Admitindo-se que o direito do consumidor seja também uma forma de intervenção do Estado na economia, na medida em que é fator ponderador da livre concorrência, ${ }^{89}$ é indispensável estabelecer as diferenças profundas entre dois capítulos muito diversos dessa intervenção: a concorrência e a defesa do consumidor.

O objetivo do direito da concorrência é a satisfação das necessidades econômicas dos indivíduos. Nesse desiderato, o direito concorrencial, que regula a competição entre os sujeitos econômicos ativos do mercado, toma por indiferente o destinatário do suprimento. Portanto, pode afirmar-se que a ênfase do direito concorrencial é essencialmente econômica, ao passo que o direito do consumidor tem uma finalidade eminentemente protetiva de um sujeito determinado. ${ }^{90}$ Em outras palavras, o direito concorrencial constitui o objeto de uma ordem pública de direção, enquanto o direito do consumidor pertence a uma ordem pública de proteção. ${ }^{91}$ Assim, embora nascidos da mesma vertente - o mercado - concorrência e defesa do consumidor defluem para destinos distintos. À raiz econômica do direito da concorrência contrapõe-se a vocação social do direito consumidor. ${ }^{92}$

Com o surgimento da legislação protetiva do consumidor, discutiu-se também a sua autonomia jurídico-disciplinar do direito que surgia. Na França, com a promulgação do Code de la consommation, em 1993, considerou-se que o direito do consumidor

o direito econômico é um é um ramo do direito. Para outros autores, o chamado direito econômico é um método, que se utiliza da mecânica dos sistemas econômicos e da análise e da interpretação do direito, levando em conta a influência dos grupos de pressão. Assim: NUSDEO, Fábio. Curso de economia: introdução ao direito econômico. São Paulo: Revista dos Tribunais, 1997, p. 240.

${ }^{87}$ COMPARATO, Fábio Konder. O indispensável direito econômico. Ensaios e pareceres de direito empresarial. Rio de Janeiro: Forense, 1978, p. 453-472.

${ }^{88}$ COMPARATO, O indispensável direito econômico, p. 465.

${ }^{89}$ Na expressão de José Afonso da Silva, é preceito condicionador da atividade econômica (SILVA, José Afonso da. Curso de direito constitucional positivo. 27. ed. São Paulo: Malheiros, 2006, p. 792).

${ }^{90}$ PAYET, Marie-Stéphane. Droit de la concurrence et droit de la consommation. Paris: Dalloz, 2001, p. 27 e ss.

${ }^{91}$ GRAU, Eros Roberto. A ordem econômica na Constituição de 1988: interpretação e crítica. 11. ed. São Paulo: Revista dos Tribunais, 2006, p. 66.

${ }^{92} \mathrm{Na}$ Constituição brasileira a defesa do consumidor é direito individual e princípio da ordem econômica, não figurando entre os direitos sociais. Entretanto, o interesse social foi corretamente posto no art. $1^{\circ}$, CDC - e é evidente. José Afonso da Silva ressalta que no anteprojeto constitucional que propôs à Comissão Afonso Arinos, incluía a proteção ao consumidor entre os direitos sociais (SILVA, José Afonso da. Curso de direito constitucional positivo. 27. ed. São Paulo: Malheiros, 2006, p. 262). Em sentido amplo, o mesmo autor inclui os direitos econômicos e culturais nos direitos sociais (SILVA, Curso, cit., p. 139). No mesmo sentido, de que os direitos dos consumidores tem natureza social: MONTEIRO, António Pinto. Breve nótula sobre a proteção do consumidor na jurisprudência constitucional portuguesa. In: Direitos fundamentais e direito privado: uma perspectiva de direito comparado. Organizadores: António Pinto Monteiro, Jörg Neuner e Ingo Sarlet. Coimbra: Almedina: 2007, p. 293-304 (301). 
constituiu-se autonomamente. ${ }^{93}$ No Brasil não foi diferente. ${ }^{94}$ Nelson Nery Júnior defende que o CDC é um microssistema, haja vista a mescla que faz de normas jurídicas de variada extração: civil, comercial, econômica, administrativa, penal, processual civil, processual penal. Dessa sorte, procura regular tanto quanto possível completamente a matéria que tem por objeto, ou seja, as relações de consumo. ${ }^{95}$ A idéia de microssistema afasta o debate sobre a natureza ou a preponderância pública ou privada do direito do consumidor. ${ }^{96}$

Antônio Herman Benjamin defendeu a autonomia do direito do consumidor por apresentar, especialmente no Brasil, todos os pressupostos indispensáveis ao esse reconhecimento: extensão da matéria, especialidade dos princípios, método próprio e processos especiais de interpretação. ${ }^{97}$

Do ponto-de-vista legislativo, embora não haja rigorosa unanimidade, são raras as vozes que discrepam de que a lei que defende os consumidores no Brasil é efetivamente um código. $^{98}$ Na Europa, a França, em 1993, e a Itália, em 1990, publicaram os seus códigos de defesa dos consumidores, mas, em verdade, nos dois países foram compiladas e sistematizadas num único diploma legal as leis já existentes, um processo mais de consolidação do que de codificação. Em Portugal, encontra-se em discussão pública o anteprojeto do Código do Consumidor, concluído em 2006. A Alemanha optou por outro caminho: por lei do ano 2000, incluiu no BGB vários preceitos de defesa dos consumidores.

\section{A defesa do consumidor e as pessoas jurídicas}

$\mathrm{Na}$ linha dos documentos internacionais, justifica-se a restrição conceitual dominante na Europa, onde, em geral, se define consumidor como a pessoa física que age com finalidade estranha a qualquer atividade empreendedora ou profissional. ${ }^{99}$

\footnotetext{
${ }^{93}$ PAYET, Marie-Stéphane. Droit de la concurrence et droit de la consommation. Paris: Dalloz, 2001, p. 19.

${ }^{94}$ Assim, entre outros: GRINOVER, Ada Pellegrini. O Código de Defesa do Consumidor no sistema sócio-econômico brasileiro. Revista da Faculdade de Direito da Universidade de São Paulo, vol. 91, 1996, p. 277-287 (280).

${ }^{95}$ NERY JÚNIOR, Nelson. A defesa do consumidor no Brasil. Revista de Direito Privado no ${ }^{\circ}$ 18, abr.-jun. 2004, p. 218-297 (221).

${ }_{96}$ Para Claudia Lima Marques, o direito do consumidor é a parte social e imperativa de um renovado direito privado. In: BENJAMIN, Antônio Herman V.; MARQUES, Claudia Lima; BESSA, Leonardo Roscoe. Manual de direito do consumidor. São Paulo: Revista dos Tribunais, 2007, p. 41.

${ }^{97}$ BENJAMIN, Antônio Herman. O Direito do Consumidor. Revista dos Tribunais, vol. 670, ago. 1991, p. 49-61 (56).

${ }_{98}$ Afirmando que se trata de uma Lei de Defesa do Consumidor, v.g.: Andrade, Fábio Siebeneichler. Da codificação: crônica de um conceito. Porto Alegre: Livraria do Advogado, 1997, p. 137. Também em posição crítica, por considerar que “a expressão ‘código' é um tanto quanto démodé” e ao mesmo tempo contraditória, pois se o CDC constitui norma especial não subsiste mais a idéia de um único código para cuidar de toda a vida privada do cidadão, conforme a concepção oitocentista: ${ }^{98}$ RODRIGUES, Geisa de Assis. A proteção ao consumidor como um direito fundamental. Revista de Direito do Consumidor, vol. 58, abr.-jun. 2006, p. 75-97 (80).

${ }^{99}$ PALMIGIANO, Alessandro; ALAIMO, Alessandra. La tutela codicistica del consumatore: i contrati di massa e le clausole vessatorie; gli artt. 1469 bis e seguenti del codice civile. In: IURILLI, Crsitiano (coordinamento a cura di). Manuale di diritto dei consumatori. Torino: G. Giappichelli, 2005, p. 22. No mesmo sentido: CALAIS-AULOY, Jean; STEINMETZ, Frank. Droit de la consommation. $7^{\text {ème }}$ éd. Paris: Dalloz, 2006, p. 7. ARCE, Alicia de Leon; MORENO-LUQUE, Carmen; CONEJO, Maria Jesus Aza.
} 
As definições legais também são geralmente restritivas, como se vê, por exemplo, no Codice del consumo italiano, de $2005,{ }^{100}$ na lei espanhola de $1984^{101}$ e na reforma do Código Civil alemão de 2000, que acolheu o conceito de consumidor como "qualquer pessoa física, que conclui um negócio jurídico, cuja finalidade não tem ligação comercial ou com sua atividade comercial”. ${ }^{102}$

A razão restritiva do conceito de consumidor às pessoas físicas advem de que o titular dos direitos humanos são os seres humanos, com o perdão do truísmo. Reconhecida a natureza de direito humano ao direito do consumidor, afirmá-lo como direito subjetivo é verdadeiro, mas, no caso dos direitos humanos, o conceito de direito subjetivo excede os limites da dogmática jurídica, amoldando-se a uma dimensão antropológica. A pessoa humana tem essência de natureza humana e existência concretamente determinada. Não é mero objeto de direito, como são os interesses nas relações jurídicas intersubjetivas ou reais, nem é impessoal como genericamente um proprietário ou qualquer outro sujeito de direito genericamente considerado o é. A pessoa humana é constituída de animalidade, racionalidade e sociabilidade. Para a sua plena realização, necessita de vida e saúde, liberdade, educação, direitos, relações, e é na sua dimensão metafísica que deve ser considerada. ${ }^{103}$

Derecho de consumo. Oviedo (Espanha), Editorial Fórum, 1995 (No será destinatário final quien adquiere bienes o servicios para volver a introducirlos em el mercado; si será desgtinatario final quien no vuelva a introducirlo en él), p. 76. PAYET, Marie-Stéphane. Droit de la concurrence et droit de la consommation. Paris: Dalloz, 2001 (Est consommateur, au sens du droit de la consommation, le consummateur final. Le consummateur intermédiaire est un proféssionnel, ou sous certaines conditions, un 'non-professionnel' "), p. 26. Em tradução livre: "Considera-se consumidor, para o direito do consumidor, o consumidor final. O consumidor intermediário é um profissional, ou em certas situações, um não-profissional”. Ao consumidor de bens se acrescenta o utente de serviços, mas sempre tendo em vista a pessoa física e suas necessidades pessoais ou familiares. A dilatação do conceito de consumidor, segundo Sabina Kirschen, põe em dúvida a sua utilidade científica (ALPA, Guido; CARLEO, Liliana Rossi (a cura di). Codice del consumo: commentario. Napoli: Edizioni Scientifiche Italiane, 2005, 46.

${ }^{100}$ 1.Ai fini del presente codice si intende per: a) consumatore o utente: la persona fisica che agisce per scopi stranei all'attività imprenditoriale o professionale eventualmente svolta. Em tradução livre: "Aos fins do presente código, entende-se por consumidor ou utente a pessoa física que age com finalidade estranha à atividade empreendedora ou profissional que eventual desenvolva”.

${ }^{101}$ Ley 26/1984, de 19 de Julio, General para la Defensa de los Consumidores y Usuarios. Art. 1. 1. (...) 2. A los efectos de esta Ley, son consumidores o usuarios las personas fisicas o jurídicas que adquieren, utilizan o disfrutan, como destinatarios finales, bienes muebles o immuebles, servicios, actividades o funciones, caulquiera que sea la naturaleza pública o privada, individual o colectiva, de quienes los producen, sumministran o expiden. 2. No trendrán la consideración de consumidores o usuarios quienes, sin constituirse destinatarios finales, adquieren, almacenem o consuman bienes o servicios con el fin de intergrarlos en procesos de producción, transformación o prestación de servicios. Em tradução livre: Para os efeitos desta lei, são consumidores ou usuários as pessoas físicas ou jurídicas que adquirem, utilizem ou desfrutem, como destinatários finais, de bens, móveis ou imóveis, de serviços, atividades ou funções, qualquer que seja a natureza pública ou privada, individual ou coletiva, de quem os produza, forneça ou expeça. Não serão considerados consumidores ou usuários aqueles que, sem se constituírem em destinatários finais, adquirem, armazenem ou consumam bens ou serviços com a finalidade de integrá-los em processos de produção, transformação ou prestação de serviços.

${ }^{102}$ Conforme MARQUES, Claudia Lima; WEHNER, Ulrich. Código Civil alemão muda para incluir a figura do consumidor: renasce o direito civil geral e social? Revista de Direito do Consumidor, nº 37, jan.-mar. 2001, p. 271-277.

${ }^{103}$ BARZOTTO, Luis Fernando. Os direitos humanos como direitos subjetivos: da dogmática jurídica à ética. In: Jurisdição e direitos fundamentais: anuário 2004-2005. Coord.: Ingo W. Sarlet. Porto Alegre: Escola Superior da Magistratura / Livraria do Advogado, 2006, p. 245-248. 
Não é o caso das pessoas jurídicas, que são fruto da criação humana e que são juridicamente reconhecidas como consumidoras na mesma medida em que são dotadas de personalidade e tem capacidade de gozo e de exercício de direitos, isto é, por outorga legal.

Assim aconteceu no nosso CDC, no qual o conceito de consumidor ultrapassou a divisa do mínimo existencial inerente à pessoa humana, ao ser incluída a pessoa jurídica como eventual consumidora (art. $2^{\circ}$, caput, considerando-se ainda as extensões conceituais do parágrafo único e dos artigos 17 e 29). Ainda assim, pode haver diferença de tratamento judicial, como permite o art. 51, I, in fine, autorizando a redução da indenização em favor de pessoa jurídica.

Ao assim legislar, o CDC leva em consideração o menor nível de desigualdade econômica que normalmente se verifica nas relações em que intervem as pessoas jurídicas na posição de consumidoras, comparativamente com o consumidor pessoa física.

Reflete-se na prática a predominante caracterização da pessoa física como consumidor, defrontando-se no pólo oposto com a pessoa jurídica como fornecedor. Segundo dados colhidos por Marcus Vinícius Motter Borges, 93,7\% dos conflitos de consumo nos juizados especializados são propostos por pessoas físicas e 48,9\% dos reclamados são pessoas jurídicas. ${ }^{104}$

\section{Maximalismo, finalismo e estrutura típica da relação jurídica de consumo}

A delimitação do conceito de destinatário final, presente no art. $2^{\circ}$, caput, CDC, necessária para estabelecer o âmbito da incidência normativa, foi - e ainda é - causa de acesas discussões entre as correntes que se tornaram conhecidas como maximalista e finalista. Não é o caso aqui de explicitar os argumentos de cada uma, ${ }^{105}$ bastando consignar que a jurisprudência, depois de prestigiar a corrente maximalista, adotou a tese oposta, mudando, especialmente no STJ, para admitir uma proteção mais restrita ao consumidor, negando-a quando o produto adquirido ou o serviço tomado visa dinamizar uma atividade produtiva, ${ }^{106}$ mas estendendo-a em favor de quem, embora

\footnotetext{
${ }^{104}$ Segundo BORGES, Marcus Vinícius Motter. “A criação das varas e juizados especializados em relações de consumo e sua efetividade”. Trabalho apresentado como requisito para aprovação na disciplina Tópicos Avançados de Direito do Consumidor na Perspectiva Constitucional, do curso de Mestrado em Direito da PUCRS. Porto Alegre, 2008, inédita. Ao autor ficam consignados agradecimentos pela cessão dos dados. 105 A este propósito, entre outras referências: PASQUALOTTO, Adalberto. O Código de Defesa do Consumidor em face do Código Civil de 2002. In: PFEIFFER, Roberto; PASQUALOTTO, Adalberto (org.). Código de Defesa do Consumidor e o Código Civil de 2002: convergências e assimetrias. São Paulo: Revista dos Tribunais, 2005, p. 131-151.

${ }^{106}$ Nesse sentido: “AGRAVO REGIMENTAL NO RECURSO ESPECIAL. HIPÓTESE DE CONSUMO INTERMEDIÁRIO. INAPLICABILIDADE DO CDC. REEXAME FÁTICO-PROBATÓRIO VEDADO. AGRAVO IMPROVIDO. 1. O Tribunal de origem assentou que o vultuoso aporte financeiro obtido junto à instituição financeira objetivava dinamizar a atividade produtiva da agravante, de modo que, em se tratando de hipótese de consumo intermediário, não se aplica o Código de Defesa do Consumidor. 2. Ademais, vale salientar que a Corte a quo, com base nos elementos de fato e prova dos autos, concluiu que os recursos obtidos foram utilizados como capital de giro pela sociedade empresária, de sorte que a pretensão da ora agravante, em aduzir que os valores não foram alocados como fomento da atividade
} 
desenvolvendo atividade econômica, se encontre em situação de vulnerabilidade. ${ }^{107}$

A mudança de orientação jurisprudencial justifica-se inteiramente diante da modificação legislativa ocorrida no país com o advento do Código Civil de 2002 e também por uma questão de conceituação estrutural da relação de consumo.

O advento do Código Civil de 2002 atualizou a legislação geral com as exigências do mundo atual, ${ }^{108}$ tornando praticamente desnecessário recorrer ao CDC, como fazia a corrente maximalista, para dar solução a questões que no Código Civil de 1916 eram ignoradas, tais como a revisão dos contratos e a responsabilidade civil objetiva. Pode o CDC, portanto, ficar adstrito ao seu papel de protetor da parte mais fraca no universo das relações de consumo e nas situações que a elas são equiparadas.

De outro lado, a análise estrutural da relação de consumo típica - ou seja, a relação jurídica entre um fornecedor e um consumidor (destinatário final) de um produto ou serviço - revela que uma empresa não pode ocupar a posição de consumidora quando adquire um produto ou contrata um serviço necessário à sua atividade econômica. A presença da empresa no mercado caracteriza-se pela continuidade das atividades que desenvolve, permanentemente voltada para a realização do seu fim social: planeja, adquire matéria prima, contrata serviços, realiza procedimentos produtivos, estoca, distribui, vende. Realiza atividades diversificadas em caráter de continuidade.

O consumidor, ao contrário, pratica atos descontínuos, não coordenados em razão de uma finalidade única: compra remédios na farmácia, alimentos na feira ou no supermercado, aluga ou adquire seu imóvel residencial ou seu automóvel, contrata serviços de assistência de saúde, de educação, de telefonia, pratica lazeres etc., sempre agindo por atos isolados uns dos outros. ${ }^{109}$

Essa diferença entre continuidade, que caracteriza a atividade econômica e descontinuidade, que é própria dos atos não-econômicos, sinaliza as posições jurídicas permanentes do fornecedor e do consumidor, mesmo quando que não se encontram em relação direta um com o outro. O empresário - e assim a empresa - exerce atividade

empresarial, não pode ser reapreciada em sede de recurso especial, sob pena de reexame fático-probatório, vedado nos termos do verbete . $^{\circ} 7$ da Súmula do STJ. 3. Agravo improvido” (STJ, AgRg nos EDcl no RECURSO ESPECIAL Nº 936.997-ES, 4 ${ }^{\mathrm{a}}$ Turma, Rel. Min. Hélio Quaglia Barbosa, 20.11.2007, unânime). 107 Nesse sentido: “CIVIL. RELAÇÃO DE CONSUMO. DESTINATÁRIO FINAL. A expressão destinatário final, de que trata o art. $2^{\circ}$, caput, do Código de Defesa do Consumidor abrange quem adquire mercadorias para fins não econômicos, e também aqueles que, destinando-os a fins econômicos, enfrentam o mercado de consumo em condições de vulnerabilidade; espécie em que caminhoneiro reclama a proteção do Código de Defesa do Consumidor porque o veículo adquirido, utilizado para prestar serviços que lhe possibilitariam sua mantença e a da família, apresentou defeitos de fabricação. Recurso especial não conhecido” (STJ, RECURSO ESPECIAL No 716.877 - SP, $3^{\text {a }}$ Turma, Rel. Min. Ari Pargendler, 22.03.2007, unânime).

${ }^{108}$ Não se ignoram as críticas formuladas contra o Código Civil de 2002 -e de algumas não se discorda -, algumas formuladas antes mesmo de sua promulgação. Assim, v.g. AZEVEDO, Antonio Junqueira de. O direito pós-moderno e a codificação. Revista de Direito do Consumidor, vol. 33, jan.-mar. 2000, p. 123-129. A atualização referida no teto diz respeito especialmente ao direito das obrigações, área comum de incidência do Código e do Código de Defesa do Consumidor.

${ }^{109}$ Sobre a contraposição entre ato e atividade: NERY, Rosa Maria B. B. de Andrade. Ato e atividade. Revista de Direito Privado, $\mathrm{n}^{\circ}$ 22, São Paulo, abr.-jun. 2005, p. 9-21. Conforme a autora, a vontade se manifesta nos negócios jurídicos do direito civil pelos atos e do direito empresarial pela atividade. 
econômica organizada para a produção ou a circulação de bens ou de serviços (art. 966, CC). Essa norma tem conteúdo coincidente com o do art. $3^{\circ}$, do CDC, que em linguagem mais prolixa define fornecedor. O exercício da atividade econômica colore a situação jurídica ${ }^{110}$ subjetiva da empresa ou do fornecedor e funcionaliza todas as suas operações. ${ }^{111}$ Ao adquirir insumos, o fabricante credita-se o imposto de circulação de mercadorias que depois repassará ao consumidor. Esse crédito tributário só é possível porque se trata de aquisição relativa a um ciclo produtivo. Os juros de um empréstimo para desenvolvimento industrial são subsidiados porque assim o dita o interesse nacional, mas somente as empresas tem acesso a ele, não os consumidores. Esses privilégios das empresas - que são justos e inerentes à sua função social - decorrem da situação jurídica que desfrutam por serem empresas e que persistem em todas as etapas da sua atividade econômica.

\section{A POLÍTICA E A EFETIVIDADE DA DEFESA DO CONSUMIDOR NO BRASIL}

Considerando-se que o mercado é uma realidade em constante transformação, não basta à efetiva defesa do consumidor a existência de um diploma legal estático. Necessita ela também de instrumentos dinâmicos, capazes de responder às constantes mudanças que se verificam na economia e na realidade quotidiana. Para isso foram instituídos uma Política Nacional das Relações de Consumo e um sistema de órgãos para formulação, coordenação e execução daquela política.

Neste capítulo serão vistos também a efetividade dos órgãos públicos envolvidos na proteção ao consumidor e a colaboração que podem advir de órgãos e de instrumentos privados.

1. A política nacional das relações de consumo como elemento dinâmico da defesa do consumidor e a sua articulação pelo Sistema Nacional de Defesa do Consumidor

As relações de consumo constituem a dinâmica do fornecimento e do abastecimento de bens e serviços, muitos de caráter existencial, tendo como cenário o mercado. Por isso o CDC não pode permanecer em posição estática, devendo ter sua aplicação adaptada às situações concretas daquela dinâmica.

Um modo de atender à necessidade de aplicação adequada foi ministrado pelo legislador mediante a formulação de princípios, cláusulas gerais e conceitos jurídicos indeterminados, como boa-fé, abusividade, expectativa legítima, a serem usados pelo juiz, dosando-os conforme as circunstâncias e possibilitando a necessária abertura do sistema normativo à realidade social.

Outra providência, esta destinada ao administrador, está presente no art. $4^{\circ}$, inciso VIII, determinando o estudo constante das modificações do mercado de consumo, de molde a formular e reformular a Política Nacional das Relações de Consumo.

\footnotetext{
${ }^{110}$ Sobre situação jurídica: CASTRO, Torquato de. Teria da situação jurídica em direito privado nacional. São Paulo: Saraiva, 1985.

${ }^{111}$ Sobre a funcionalidade das situações subjetivas: PERLINGERI, Pietro. Perfis do direito civil. Tradução de Maria Cristina De Cicco. Rio de Janeiro: Renovar, 2002, p. 106.
} 
A PRNC é o instrumento essencial de acompanhamento do mercado e de suas mutações. Tal como está posta e inclusive grafada na lei adquire um inegável caráter institucional, como registra José Reinaldo de Lima Lopes, ${ }^{112}$ o que significa que não é um programa transitório nem de um governo. Impõe-se, ao contrário, como obrigação à autoridade pública, especialmente ao Poder Executivo nos três níveis da Federação, pois todos integram o Sistema Nacional de Defesa do Consumidor (art. 105), cabendo ao Departamento Nacional de Defesa do Consumidor, alojado na estrutura do Ministério da Justiça, a tarefa central de coordenação (art. 106). No aspecto temporal, resulta do caráter institucional da PRNC a sua permanência e continuidade além dos mandatos eletivos, pois o dever de proteção ao consumidor imposto pela Constituição tem como sujeito passivo o Estado e não o governo. A implementação da PRNC, pela edição de normas jurídicas de qualquer hierarquia, constitui direito dos consumidores em forma de exigibilidade de prestações normativas a serem cumpridas pelo Estado. ${ }^{113}$

Na feliz expressão de Walter José Faiad de Moura, a PRNC estabeleceu "um projeto educativo à sociedade de consumo”, embora esteja carente de implementação. ${ }^{114}$

Os objetivos da PRNC, enunciados no caput do art. $4^{\circ}$, em suma, é o resguardo dos direitos básicos do consumidor, listados no art. $6^{\circ}$ : respeito à sua dignidade, saúde e segurança, proteção dos seus interesses econômicos, melhoria da sua qualidade de vida, transparência e harmonia das relações de consumo.

A formulação da PRNC deve obedecer aos princípios que o art. $4^{\circ}$ enumera, mas, como observa José Reinaldo de Lima Lopes, o texto contem muitas ambiguidades. ${ }^{115}$ Com efeito, a vulnerabilidade aparece no inciso I como um pressuposto da PRNC, mas os demais incisos mais contem objetivos (normas-objetivo) a serem alcançados do que propriamente princípios. ${ }^{116}$

O inciso II arrola quatro diretrizes para a ação governamental, que podem ser resumidas em duas: a) iniciativa direta, agindo diretamente no mercado com função

\footnotetext{
${ }^{112}$ LOPES, José Reinaldo de Lima. Direito civil e direito do consumidor: princípios. In: PFEIFFER, Roberto; PASQUALOTTO, Adalberto (org.). Código de Defesa do Consumidor e o Código Civil de 2002: convergências e assimetrias. São Paulo: Revista dos Tribunais, 2005, p. 83-130 (100).

113 Sobre prestações normativas dom Estado: ALEXY, Robert. Teoria dos direitos fundamentais. Trad. Virgílio Afonso da Silva. São Paulo: Malheiros, 2006, p. 202.

${ }^{114}$ MOURA, Walter José Faiad. O dever de educar. Revista de Direito do Consumidor, vol. 60, out.-dez. 2006, p. 212-233 (215).

${ }^{115}$ LOPES, José Reinaldo de Lima. Direito civil e direito do consumidor: princípios. In: PFEIFFER, Roberto; PASQUALOTTO, Adalberto (org.). Código de Defesa do Consumidor e o Código Civil de 2002: convergências e assimetrias. São Paulo: Revista dos Tribunais, 2005, p. 83-130.

116 Adota-se aqui, tal como José Reinaldo de Lima Lopes no texto citado, a dupla compreensão de princípios de Miguel Reale: como "verdades ou juízos fundamentais que servem de alicerce ou de garantia de certeza a um conjunto de juízos, ordenados em um sistema de conceitos relativos a dada porção da realidade", ou como "proposições que, apesar de não serem evidentes ou resultantes de evidências, são assumidas como fundantes da validez de um sistema particular de conhecimentos, como seus pressupostos necessários” (REALE, Miguel. Filosofia do direito. $1^{\circ}$ vol. 20. ed. São Paulo: Saraiva, 2002, p. 60). A vulnerabilidade do consumidor adapta-se aos dois conceitos, pois no mercado de consumo atual é evidente por si só a posição desvantajosa do consumidor frente aos fornecedores e é essa posição de debilidade que confere validez ao sistema do CDC.
} 
orientadora ou fiscalizadora, no que se inclui o exercício do poder de polícia, perfazendo camadas dos conteúdos normativos das alíneas “a”, “c” e “d”; b) indução, por meio de incentivos à criação e desenvolvimento das associações de consumidores - perfazendo inteiramente a previsão da alínea "b” - também agindo junto às empresas no sentido de incentivar a melhoria dos padrões de qualidade (alínea “d”).

No que tange à criação de associações de consumidores, a atuação governamental ainda é escassa, ${ }^{117}$ mas o tema é de relevância, porque diz respeito ao ativismo da cidadania, dotando a coletividade de autonomia e ao mesmo tempo desonerando os próprios órgãos públicos de muitas tarefas que atualmente eles desenvolvem. Basta pensar na expressiva desproporção de ações coletivas propostas pelo Ministério Público frente às que são levadas a juízo pelas entidades privadas. Embora poucas associações tenham papel de destaque, é justo referir a grande contribuição oferecida à causa dos consumidores pelo IDEC - Instituto de Defesa do Consumidor, ${ }^{118}$ fundado em São Paulo em 1987 e mantido exclusivamente com a contribuição dos seus associados. Sem prejuízo de outras poucas instituições modelares e embora de menor porte, também merece citação a ADECON, ${ }^{119}$ de Recife, fundada em 1999.

A harmonização das relações de consumo e a compatibilização da proteção do consumidor com a necessidade de desenvolvimento econômico e tecnológico (inciso III) é uma finalidade a atingir, no difícil equilíbrio entre a tutela do mais fraco e a liberdade do mais forte. Este é o ponto de encruzilhada de questões difíceis, como os riscos do desenvolvimento, que ensejam a dúvida entre debitar às empresas ou aos consumidores o ônus de suportar os danos decorrentes de produtos seguros no momento do seu lançamento, mas que se revelam nocivos no uso por descobertas científicas posteriores. È nesse campo que deve ser definitivamente derrotada a idéia (quanto haverá de utópico nisso?) de antagonismo entre as empresas e os consumidores, que era dominante anos atrás, como é admitido na apresentação conjunta dos Ministros da Indústria e Comércio e da Justiça à coletânea de textos legais sobre as relações de consumo:

O entendimento do Ministério da Indústria e do Comércio através do Conselho de Desenvolvimento Comercial é o de que o surgimento das associações de consumidores é fato normal em uma sociedade pluralista; mas não com ênfase na conotação - aqui pejorativa - de "defesa do consumidor”, pois o comerciante não é hostil aos que adquirem bens e serviços; ao contrário, serve a estes. ${ }^{120}$

O inciso IV toca na questão essencial da educação e informação dos consumidores, que assume maior importância em face da desigualdade social, determinante de um

\footnotetext{
${ }^{117}$ O site do DPDC fornece um roteiro para a sensibilização da sociedade, criação e oficialização das associações, disponível em http:/www.mj.gov.br/data/Pages/MJF1FE712CITEMID1A043C3025C44DC6A 708013D00747459PTBRIE.htm. Acesso em 06 ago. 09.

${ }^{118} \mathrm{http}: / /$ www.idec.org.br/

119 http://www.adecon-pe.org.br/

${ }^{120}$ BRASIL. Relações de consumo. 2. ed. MIC/Conselho de Desenvolvimento Comercial e Fundação Petrônio Portella, 1983, 4 v (Coleção textos legais, 8), v. 1, p. I.
} 
acentuado desnível informacional. ${ }^{121}$ Também aqui não se trata de um princípio propriamente dito, mas de mais uma diretriz de ação. Cabe ao Estado ministrar educação e informação aos consumidores no âmbito do art. $4^{\circ}$; já no art. $6^{\circ}$, III, o devedor da informação são os fornecedores. A atuação do Estado se dá de forma indireta, propiciando os meios educativos e informativos, ou impondo coercitivamente às empresas que o façam, como acontece com a obrigatoriedade de informação da composição dos alimentos no rótulo das embalagens.

A atuação direta do Estado manifesta-se de vários modos, sendo que uma das principais é a introdução de temas de consumo no currículo das escolas fundamentais, como prevê o Plano Nacional de Educação em vigor, baixado pela Lei 10.172, de 09.01.2001. A previsão normativa, entretanto, carece de implementação na maioria das escolas.

O inciso V prevê o incentivo à criação, nas empresas, de controles de qualidade e segurança e de mecanismos alternativos de solução de conflitos de consumo. A intenção é meritória, mas nesse campo também pouco tem sido feito. Como resposta a esse dispositivo, as empresas instituíram os Serviços de Atendimento ao Consumidor - SACs -, mas muitos desses serviços transformaram-se em atendimentos burocráticos, procrastinatórios e não confiáveis, quando não são feitos exclusivamente por telefone, deixando exasperados os consumidores que se submetem a maratonas eletrônicas, sem um atendimento personalizado digno. Para combater esse mal que se generalizou, foi editado o Decreto Federal 6.523/08, regulamentando o Serviço de Atendimento ao Consumidor por telefone, cuja implantação, todavia, não foi pacífica e ainda apresenta notória desobediência.

O inciso VI trata de questões paralelas à defesa do consumidor, mas que nela repercutem, especialmente ligadas à concorrência. $\mathrm{O}$ Estado se compromete a coibir e reprimir os abusos do poder econômico e a concorrência desleal, inclusive a utilização indevida de inventos, nomes, marcas e signos que possam causar prejuízos aos consumidores. Há legislação própria nesse sentido, v.g., a Lei 8.884/94, a chamada lei antitruste, que dispõe sobre a prevenção e a repressão às infrações contra a ordem econômica. A concorrência, de um lado, é incentivada, porque é essencial à liberdade de mercado, mas de outro lado, deve ser contido dentro de limites éticos, nos quais se inclui o respeito aos concorrentes e à dignidade do consumidor. Entretanto, a regulação da concorrência não basta para a defesa do consumidor. Como bem observa Carlos Ferreira de Almeida, tradicionalmente as regras de concorrência foram referidas ao comportamento das empresas, ignorando a relação direta com os consumidores, como se o mercado fosse apenas constituído de oferta, bastando cuidar das suas condições, sem dar atenção à demanda. ${ }^{122}$ Em idêntico ponto-de-vista, Fábio Konder Comparato anota que a sistemática proteção do consumidor era estranha à teoria econômica clássica, tendo proposto, em escrito

${ }^{121}$ MOURA, Walter José Faiad. O dever de educar. Revista de Direito do Consumidor, vol. 60, out.-dez. 2006, p. 212-233 (220). Com razão destaca Moura: "Consumidores desinformados e sem poder algum de avaliação estão mais expostos a lesões praticadas no mercado, impossibilitados de enxergar ou compreender onde está o seu prejuízo” (MOURA, Ob. cit., p. 224).

${ }^{122}$ ALMEIDA, Carlos Ferreira de. Os direitos dos consumidores. Coimbra: Almedina, 1982, p. 74. 
pioneiro, a adoção de medidas de proteção ao consumidor, entendendo-a como um capítulo importante do direito econômico. ${ }^{123}$

Para a execução da PNRC, dispõe o art. 5º, CDC, haverá assistência jurídica, integral e gratuita para o consumidor carente, Promotorias de Justiça, delegacias de polícia, juizados especiais e varas especializadas, além de estímulos à criação e desenvolvimento das associações de consumidores.

Muitas dessas medidas não passaram de propósitos do legislador e outras talvez até contenham um certo grau de equívoco, como se verá abaixo.

Não há dúvidas de que a assistência jurídica em favor do consumidor carente é imprescindível e nesse quesito é possível afirmar que houve sensível progresso no país em geral, com a instituição das Defensorias Públicas, que vem cumprindo essa missão em alguns Estados com grande brilho, como é o caso - para ressaltar dois do Rio de Janeiro e do Rio Grande do Sul. ${ }^{124}$

A Defensoria Pública do Estado do Rio Grande do Sul, por exemplo, em 2008, ajuizou ações coletivas de consumo contra as nove maiores instituições bancárias do país, visando o ressarcimento dos poupadores por prejuízos decorrentes dos Planos Econômicos Bresser (1987), Verão (1989), Collor I e Collor II (1991-1992). O ajuizamento dessas ações repercutiu em aproximadamente 10.000 ações singulares que estavam em curso no poder judiciário do Rio Grande do Sul, e que foram suspensas no aguardo da decisão definitiva das ações coletivas que poderão favorecer os autores individuais. ${ }^{125}$

No Rio de Janeiro, o NUDECON - Núcleo do Consumidor da Defensoria Pública estadual, que tem atuação apenas na capital fluminense, ajuizou 6.852 ações de variada natureza em 2008, contabilizando 19.623 pessoas atendidas e 1.837 audiências de conciliação. É autor de mais de 50 ações civis públicas. O NUDECON dá atendimento preferencial a consumidores superendividados. ${ }^{126}$

No âmbito privado, o art. 107, CDC, criou um instrumento de largo alcance na regulação das relações de consumo, mas que permanece apenas na letra da lei: a convenção coletiva de consumo. São legitimados para convencioná-la, de um lado, as associações de consumidores e, de outro, as associações de fornecedores e os sindicatos de categoria econômica. Seu objeto pode ser o estabelecimento de condições relativas a preço, qualidade, quantidade, garantia e características de produtos e serviços.

A convenção coletiva seria um instrumento apto especialmente a prevenir conflitos de consumo se fosse posta em prática. Sua inspiração, sem dúvida, é a convenção coletiva de trabalho, de larga utilização na regulamentação das relações trabalhistas. Não se pode explicar a discrepância pelo fato de que os trabalhadores

${ }^{123}$ COMPARATO, Fábio Konder. Ensaios e pareceres de direito empresarial. Rio de Janeiro: Forense, 1978, p. 473-499.

${ }^{124}$ A citação desses dois Estados apenas, feita em caráter ilustrativo, é uma limitação deste estudo e não significa excluir o trabalho meritório da instituição da Defensoria Pública nos demais Estados onde ela atua.

${ }^{125}$ Dados disponíveis no site http://www.dpe.rs.gov.br/site/arquivos/rel_atividades2008.pdf. Acesso em 05 ago. 2009.

${ }^{126}$ Informações fornecidas pela Coordenadora do NUDECON, Defensora Pública Marcella Oliboni. 
tem interesses homogêneos e os consumidores não, uma vez a convenção de consumo incidiria sobre interesse determinado, no qual a homogeneidade também estaria presente. Podem exemplificar a utilidade da convenção de consumo: as condições de registro devedores em cadastros de inadimplentes; a conciliação extrajudicial em casos de superendividamento; ${ }^{127}$ a convenção sobre condições gerais em contratos de adesão em setores específicos como seguros, planos de saúde, crédito, serviços educacionais etc.

\section{A participação do Poder Judiciário na defesa do consumidor}

Segundo o art. $5^{\circ}$, inciso IV, CDC, a execução da Política Nacional das Relações de Consumo deveria contar com a criação de Juizados Especiais de Pequenas Causas (nomenclatura da época da promulgação do CDC e que na Lei 9.099, de 26/9/95, adotaram a designação de Juizados Especiais Cíveis) e de Varas Especializadas para a solução dos litígios de consumo.

Poucos Estados seguiram a recomendação legal, apenas, pelo que foi dado apurar, a Bahia, o Espírito Santo, Goiás, Mato Grosso, Mato Grosso do Sul, Minas Gerais e o Pará. Em Salvador, Belo Horizonte e Belém há dois juizados especiais em cada capital, e no interior apenas na Bahia, nas comarcas de Feira de Santana, Ilhéus e Itabuna. No Estado de São Paulo chegaram a ser criadas por lei as varas especializadas, mas nunca foram instaladas e acabaram sendo transformadas em juízos cíveis comuns.

Não obstante a escassa criação de juizados especializados, as relações de consumo são a maioria dos processos em curso nos juizados especiais. ${ }^{128}$ Caso peculiar é o da Bahia, cuja lei - a Lei Estadual 6.982, de 25.08.1996 - criou os juizados especializados com competência para causas de valor superior a quarenta salários mínimos, invertendo a lógica da proteção ao mais fraco.

O problema mais agudo dos juizados e das varas especiais é o da competência. Com a especialização, cria-se uma competência em razão da matéria, de caráter absoluto, portanto. Demandado, a defesa mais imediata do fornecedor é a alegação de que a causa não envolve relação de consumo, propiciando a argüição da incompetência do juízo ou a suscitação de conflito de ofício, o que invariavelmente acarreta longa discussão procrastinatória em detrimento da celeridade da decisão de mérito, que

\footnotetext{
${ }^{127}$ Sempre que se refere este assunto, não é possível deixar de mencionar o inédito trabalho no Brasil desenvolvido no Rio Grande do Sul pelas juízas de direito Clarissa Costa de Lima e Káren Rick Danilievicz Bertoncello, que, ao arrepio da existência de legislação própria, dedicam-se à conciliação entre credores e devedores superendividados, com elevadíssimo grau de eficiência. O trabalho foi reconhecido com menção honrosa no Prêmio Innovare 2008, certame promovido pelo Ministério da Justiça. Sobre o tema: LIMA, Clarissa Costa de; BERTONCELLO, Káren Rick Danilievicz. Tratamento do crédito ao consumo na América Latina e superendividamento. In: MARQUES, Claudia Lima; CAVALAZZI, Rosângela Lunardelli. Direitos do consumidor superendividado: superendividamento e crédito. Biblioteca de Direito do Consumidor, v. 29. São Paulo: Revista dos Tribunais, 2006.

${ }^{128}$ As informações aqui utilizadas devem-se ao trabalho já referido de Marcus Vinícius Motter Borges, coletados para integrar a monografia "A criação das varas e juizados especializados em relações de consumo e sua efetividade”, apresentada como requisito para aprovação na disciplina Tópicos Avançados de Direito do Consumidor na Perspectiva Constitucional, do curso de Mestrado em Direito da PUCRS. Porto Alegre, 2008, inédita. Os dados são de 2002, embora tenham sido coligidos em 2008, não havendo, então, informações mais atualizadas disponíveis.
} 
afinal é o que interessa ao consumidor. Frustra-se assim a boa intenção do legislador. Ao que parece, a maioria dos Estados percebeu a inconveniência de seguir a diretriz do legislador federal e omitiu-se - ou o fez inadvertidamente, acertando por via transversa.

A mesma inconveniência não se verifica com a criação das varas preferenciais, pois nestas a competência não é exclusiva. As varas preferenciais podem atender em regime de as ações coletivas - não apenas de consumo - distribuindo-se as singulares entre todas as demais. Essa providência especializa os magistrados e não determina problemas de competência.

3. As sanções administrativas e penais como garantias secundárias da proteção ao consumidor

O capítulo penal da proteção ao consumidor, especialmente, é inconveniente e inoportuno para muitos que defendem o chamado direito penal mínimo. O argumento, suficientemente conhecido, é que a lei penal deveria limitar-se a resguardar os valores fundamentais da pessoa e da sociedade, sob pena de banalização e ineficácia do sistema, como se constata atualmente com uma generalizada sensação de impunidade. Em grande parte, a causa de desilusão social com o sistema penal estaria na multiplicação de tipos penais, produzindo um resultado inverso do esperado, de modo a contribuir para o aumento da criminalidade, ao invés de acentuar os efeitos preventivo e repressivo.

À parte as impropriedades técnicas cometidas pelo legislador, como a edição da Lei 8.137, de 27.12.1990, com tipos em parte redundantes e em parte incongruentes com as normas penais do CDC, que estava em vacatio legis, a criminalização de condutas contrárias às normas de proteção do consumidor corresponde ao que Ferrajoli classifica de garantia secundária dos direitos fundamentais. Para o autor italiano, os direitos fundamentais constituem-se de garantias primárias, que são as obrigações de prestações [o Estado deverá promover a defesa do consumidor, segundo art. $5^{\circ}$, XXXII, da CF] e as proibições de lesões e garantias secundárias. Estas são justamente as obrigações de reparação ou sanção judicial às lesões aos direitos protegidos. ${ }^{129}$

\section{Novos dados e sinais}

A prova de que a falta de efetividade das normas de proteção ao consumidor é a omissão do Estado é dada por informações do próprio Ministério da Justiça, cuja estrutura abriga o Departamento Nacional de Defesa do Consumidor. ${ }^{130}$ Segundo informações contidas na página eletrônica do $\mathrm{MJ},{ }^{131}$ um ano após a publicação do Decreto 6.523/08, que regulamentou o Serviço de Atendimento ao Consumidor por

\footnotetext{
${ }^{129}$ FERRAJOLI, Luigi. Derechos y garantias: la ley del más débil. Tradução para o espanhol de Perfecto Andrés Ibáñez e Andréa Greppi. 2. ed. Madrid: Editorial Trotta, 2001, p. 43.

${ }^{130}$ Apenas para ilustrar: Bernard Madoff, o financista norte-americano que deu um golpe de 65 bilhões de dólares, lesando milhares de poupadores cujos recursos administrava fradulentamente, declarou que seu crime foi possível porque as autoridades reguladoras dos Estados Unidos não estavam atentas. Notícia captada em 29 jul. 2009 em

http://br.invertia.com/noticias/noticia.aspx?idNoticia=200907291917_EFE_78265391.

${ }^{131}$ http://www.mj.gov.br/data/Pages/MJ08DEBD27ITEMID322CD76F3F144AB09C69CAB0B1FFFC10 PTBRIE.htm, acesso em 29 jul. 2009.
} 
telefone, as empresas de telefonia - paradoxalmente - continuavam apresentando o mais alto índice de insatisfação dos consumidores, atingindo $57 \%$ do total de reclamações dirigidas aos órgãos do Sistema Nacional de Defesa do Consumidor. Reconhece o Ministério da Justiça que as empresas agem conforme o custo-benefício, entendendo ser mais econômico suportarem as multas ou eventuais demandas individuais do que se adaptarem à conduta devida e acarretando com os custos implicados. ${ }^{132}$ Nada obstante, os Procon's de vários Estados aplicaram, nesse período, um total aproximado de 3,5 milhões de reais em multas às duas principais operadoras de telefonia, sendo São Paulo um caso à parte, onde as sanções ultrapassaram 10 milhões de reais. ${ }^{133}$ A omissão do Estado, que aqui e ali apresenta avanços, é histórica e persiste na maioria dos casos.

A mesma página citada dá notícia alentadora do ajuizamento de ações judiciais inéditas pelo Sistema Nacional de Defesa do Consumidor, pedindo a condenação das duas empresas ao pagamento de indenização por danos morais coletivos aos consumidores que soma o valor de 300 milhões de reais, a ser recolhido, em caso de procedência, ao Fundo de Direitos Difusos. Ainda que tardia, a providência é saudável e anuncia-se que será repetida no segundo setor de maior número de reclamações, com $17 \%$ do total, o de cartões de crédito.

A notícia deve ser recebida como benfazeja mudança de atitude da administração pública, que em grande parte pode ser creditada à estabilidade - ainda que ocasional - da chefia do DPDC, que se mantém a mesma desde o primeiro período da atual administração federal, em que pese a troca de vários ministros.

Essa estabilidade vem produzindo outros frutos benéficos no DPDC, como a criação da Escola Nacional de Defesa do Consumidor e a implantação do Sindec Sistema Nacional de Informações de Defesa do Consumidor. Na mesma esteira de estabilidade e produtividade vem operando nos últimos anos o Procon-RS, que também criou a sua Escola de Defesa do Consumidor, a entrar em operação, e vem dedicando-se à implantação de Procon’s municipais. Mesmo assim, só existem órgãos públicos de defesa do consumidor em 59 dos 494 municípios do Estado, pouco mais de dez por cento. O Estado de São Paulo conta com 210 Procon's municipais para um total de 645 municípios, aproximadamente um terço, o índice mais alto do país.

Entretanto, por que na imensa maioria dos Estados - embora haja exceções pontuais, insista-se - os Procon's e órgãos afins não apresentam o mesmo desempenho? O problema, que afeta inclusive os órgãos de atuação mais destacada, é de natureza política.

\footnotetext{
${ }^{132}$ Em 1994, no II Congresso Nacional de Defesa do Consumidor, em Brasília, o plenário testemunhou, espantado, a confissão de um diretor de banco (não banqueiro tradicional, diga-se passagem, mas ocasionalmente ocupando uma diretoria de banco estatal), de que as cláusulas leoninas não eram acidentais nos contratos bancários, mas conseqüência de um frio cálculo de custo-benefício, em vista do alto índice de resignação dos mutuários. O cinismo, menos da declaração do que da conduta, apenas corrobora a distinção conceitual feita por Max Weber entre ordem jurídica e ordem econômica, acima citada (WEBER, Max. Economia e sociedade. Vol. 1. Tradução de Regis Barbosa e Karen Elsabe Barbosa. 3. ed. Brasília: Editora Universidade de Brasília, 2000, p. 209).

${ }^{133}$ Segundo se colhe em http://www.procon.sp.gov.br/noticia.asp?id=1219. Acesso em 30 jul. 2009.
} 
Os órgãos da administração pública que integram o Sistema Nacional de Defesa do Consumidor - o DPDC e os Procon's estaduais e municipais - são encarregados da fiscalização das relações de consumo, podendo apurar e punir as infrações que verificarem (artigos $4^{\circ}$, inc. III e $5^{\circ}$, caput, do Decreto $n^{\circ} 2.181$, de 20.03.1997, que baixou o regulamento administrativo do CDC. A esses órgãos, portanto, foi delegado o poder de polícia das relações de consumo. A sua estrutura, porém, não corresponde à importância da tarefa cometida. Não são dotados de quadros de servidores públicos estáveis (já nem se fala de boa remuneração), indispensáveis ao exercício das funções fiscalizatória e sancionadora. O provimento dos cargos é por comissão, o que em regra significa ficar à mercê de conveniências políticas. $\mathrm{O}$ resultado é geralmente a subordinação a interesses paroquiais ditados pelas alianças que decidem eleições ou sustentam governos. Imagine-se um fiscal do Procon decidido a autuar um comerciante infrator que financia a campanha do Prefeito. Provavelmente ficará sem emprego, se é que em algum momento a idéia da atuação passou pela sua cabeça.

\section{CONCLUSÃO}

A defesa jurídica do consumidor chegou ao nosso país seguindo uma tendência internacional e deu-se por via da Constituição de 1988. Seus reflexos foram imediatos, produzindo um grande avanço na modernização do direito privado nacional, numa época de desatualização do Código Civil. O CDC, promulgado em obediência a mandamento do constituinte, preencheu uma lacuna no nosso direito positivo, permitindo maior base legal para decisões judiciais mais compatíveis com o estágio econômico e social do país ao final do século XX.

Atualmente, consolidada a eficácia do CDC na regulação imediata das relações de consumo, são exploradas as virtualidades da posição constitucional da defesa do consumidor, situada no patamar culminante dos direitos fundamentais e em interação com outros valores máximos protegidos na Constituição.

As altas especulações doutrinárias, todavia, não podem obscurecer o fato de que a implementação efetiva de muitos mecanismos de defesa do consumidor ainda esperam por providências concretas - e em geral a mora nessa implementação é do Estado.

No permanente debate sobre o tamanho do Estado, é preciso lembrar de precedentemente discutir-se que sociedade se quer. A valer o que está na Constituição, que adota como fundamentos da República a cidadania, a dignidade da pessoa humana, e como objetivos uma sociedade livre, justa e solidária, a defesa do consumidor, erigida como direito subjetivo público e como princípio da ordem econômica, não dispensa uma atuação independente de agentes estatais capacitados nos órgãos de fiscalização. O que se verifica, ao contrário, é que os Procon’s não tem quadros de carreira, sendo constituídos por funcionários em regime comissionado, suscetíveis de se transformar em massa de manobra de interesses partidários. Além de gerar a ineficácia de normas importantes como as sanções administrativas do CDC, esse estado de coisas causa a distorção de uma função nobre da responsabilidade civil, que é a reparação do dano moral. Desassistido em sua luta desigual contra o oponente poderoso, o consumidor socorre-se do Judiciário para ver restaurada uma situação 
que não é singular, mas coletiva e repetitiva, ou seja, a infração contumaz que certos fornecedores praticam conscientemente, apostando na relação custo-benefício, pois se locupletam com a infração que dolosamente praticam, ainda que eventualmente tenham que pagar algo a algum consumidor isoladamente quantia muitas vezes inferior à que auferem abusivamente. A verdadeira correção deveria vir das sanções estatais, por via dos Procon's, não só pela imposição de multas, mas por medidas mais drásticas como a suspensão de atividades, na progressão repressiva. Aí sim teríamos uma melhoria nas relações de mercado, sem detrimento das empresas que, no cumprimento da sua indispensável função social, agem com lisura e respeito ao consumidor, fazendo concorrência leal e produtiva.

Outros exemplos poderiam ser aqui alinhados para demonstrar a omissão do Estado, mas este basta para convencer que a defesa do consumidor no Brasil, em que pese todo o prestígio que já alcançou, é um tema que ainda não subiu aos palanques eleitorais.

De outra parte, os consumidores não precisam esperar tudo do Estado, podendo tomar as suas iniciativas. Podem congregar-se em associações de defesa coletiva, ganhando legitimidade formal para propor ações, tornando-se protagonistas de sua própria história e estabelecendo uma interlocução direta com os fornecedores e as autoridades públicas. 